NBER WORKING PAPER SERIES

\title{
HOW COUNTRY AND SAFETY-NET CHARACTERISTICS AFFECT BANK RISK-SHIFTING
}

\author{
Armen Hovakimian \\ Edward J. Kane \\ Luc Laeven \\ Working Paper 9322 \\ http://www.nber.org/papers/w9322
}

\author{
NATIONAL BUREAU OF ECONOMIC RESEARCH \\ 1050 Massachusetts Avenue \\ Cambridge, MA 02138
}

November 2002

The authors would like to thank Robert Bliss, Gerard Caprio, Stijn Claessens, James Thomson, and seminar participants at the Federal Reserve Bank of Chicago, Hitotsubashi and Depaul Universities, and the Seventh Annual Meeting fo the Latin American and Caribbean Economic Association in Madrid, for helpful comments on earlier drafts of the paper. The views expressed herein are those of the authors and not necessarily those of the National Bureau of Economic Research.

(C) 2002 by Armen Hovakimian, Edward J. Kane and Luc Laeven. All rights reserved. Short sections of text, not to exceed two paragraphs, may be quoted without explicit permission provided that full credit, including (C) notice, is given to the source. 
How Country and Safety-Net Characteristics Affect Bank Risk-Shifting

Armen Hovakimian, Edward J. Kane and Luc Laeven

NBER Working Paper No. 9322

November 2002

JEL No. G21, G28, F33

\begin{abstract}
Risk-shifting occurs when creditors or guarantors are exposed to loss without receiving adequate compensation. This paper seeks to measure and compare how well authorities in 56 countries controlled bank risk shifting during the 1990s. Although significant risk shifting occurs on average, substantial variation exists in the effectiveness of risk control across countries. We find that the tendency for explicit deposit insurance to exacerbate risk shifting is tempered by incorporating loss-control features such as risk-sensitive premiums, coverage limits, and coinsurance. Introducing explicit deposit insurance has had adverse effects in environments that are low in political and economic freedom and high in corruption.
\end{abstract}

\author{
Edward J. Kane \\ Armen Hovakimian \\ Luc Laeven \\ Boston College \\ Baruch College \\ World Bank \\ Finance Department \\ Fulton Hall 330A \\ Chestnut Hill, MA 02467 \\ and NBER \\ edward.kane@bc.edu
}


October 11, 2002

\section{How Country and Deposit Insurance Characteristics Affect Bank Risk-Shifting}

Even when its long-run effects are adverse, instituting deposit insurance can benefit short-horizoned policymakers and politicians. As long as its guarantees remain credible, explicit insurance promises to eliminate the threat of depositor runs and to protect depositors from harm with only a smidgen of its true economic cost actually registering on the official government budget.

Part of the long-run cost of deposit insurance is that it reduces incentives for depositors to monitor and police their banks. In countries that have not introduced deposit insurance explicitly, insurance still exists in an implicit form. The costs and benefits society experiences from either type of guarantees depend on how effectively government regulators can control bank risk-shifting (Buser, Chen, and Kane, 1981; Brickley and James, 1988; Calomiris, 1992; Kane, 1995; Honohan and Klingebiel, 2001).

Risk-shifting occurs whenever a contractual counterparty is exposed to loss from fraud, leverage or earnings volatility without receiving adequate compensation for the risk entailed. Other things equal, a bank can shift risk onto its deposit insurer in two principal ways: by increasing its leverage and by increasing the volatility of its return on assets. Risk-shifting is subsidized whenever the value of the explicit and implicit deposit guarantees a country's banks enjoy exceeds the implicit and explicit premiums the insurer imposes on them. To avoid subsidizing bank risk taking, a deposit insurer must monitor increases in volatility and leverage and police them appropriately. 
The empirical literature on bank risk-shifting begins with Marcus and Shaked (1984). Employing U.S. data and a single-equation framework, these authors use a oneyear put option model to estimate a risk-adjusted "fair" value for a bank's deposit insurance premium. These authors and subsequent research by Ronn and Verma (1986) find that on average FDIC insurance was overpriced, but that the distribution of fair premiums was strongly skewed to the right. Pennacchi (1987a and b) shows that this skewness gains importance when deposit insurance is analyzed in a multiperiod context inasmuch as evidence of average underpricing emerges in long-maturity models.

Improving on these single-equation models, Duan, Moreau and Sealey (1992) separate the effects of leverage and return volatility in testing for risk shifting during 1976-1986 using a sample of thirty large U.S. banks, they found that twenty percent showed risk-shifting behavior. Using this triangular two-equation framework and fitting both single-period and infinite-maturity option models of deposit-insurance value, Hovakimian and Kane (2000) examine risk-shifting in 1985-1994 for a sample of 123 U.S. banks. They find that on average capital regulation did not prevent sample banks from shifting risk. Risk-shifting proved particularly strong for poorly capitalized banks and for banks with high ratios of insured deposits to insured debt.

Laeven (2002a) fits the single-equation option model to a sample of banks in several countries. He interprets estimates of the fair (i.e., properly priced) deposit insurance premium (IPP) as a proxy for bank risk and shows that this proxy helps to forecast bank distress in different countries. Laeven (2002b) investigates how countryspecific and bank-specific features contribute to the value of insurance services. The opportunity-cost value of deposit insurance services proves higher in countries with 
explicit deposit insurance, but its contribution to bank stock prices disappears in countries with high-quality and well-enforced legal systems.

Kane (2000) argues that the value of a country's financial safety net should respond to country-specific variation in risk control: differences in informational environments and in the enforceability of private contracts in particular. Demirgüç-Kunt and Kane (2002) contend that explicit deposit insurance generates costly subsidies in countries whose institutional environment is weak. Demirgüç-Kunt and Detragiache (2002) find cross-country evidence that, in countries with weak institutional environments, explicit deposit insurance increases the probability of banking crises.

Using Hovakimian and Kane's (2000) adaptation of the two-equation regression model introduced by Duan, Moreau, and Sealey (1992), this paper focuses on how well authorities in 56 countries controlled risk-shifting incentives in recent years. Although we find significant risk shifting on average, our method allows us to model how the effectiveness of risk control differs across countries. As hypothesized in Kane (2000), differences in the value of IPP across countries are explained by differences in depositinsurance design features and in environmental measures of political repression, economic freedom, and government corruption. Specifically, we find that introducing explicit deposit insurance may exacerbate risk shifting, but that this effect is tempered when loss-control features such as risk-sensitive deposit insurance premiums, coverage limits, and coinsurance are incorporated into the deposit-insurance system. We also find that introducing explicit deposit insurance expands risk-shifting opportunities in environments that are low in political and economic freedom and high in corruption. 
Regression results confirm that recent adopters of explicit insurance have done a particularly poor job of managing the value of their deposit guarantees.

The paper proceeds as follows. Section I introduces the methods used to model bank risk-shifting behavior. Section II describes the sources of our data and our sampling procedures. Section III presents and interprets estimates of risk-shifting incentives. In this section and in Section IV, the analysis focuses on how risk-shifting differs across countries that manage their deposit insurance system in different ways and under different circumstances. Section V summarizes our findings.

\section{Role of Alternative Deposit-Insurance Models}

This section describes procedures for estimating risk-shifting opportunities at individual banks. Merton $(1977,1978)$ shows that, other things equal, the fair insurance premium (expressed as a percentage of deposits) increases with a bank's leverage and with the volatility of its returns. Our tests employ a linear version of this relation:

$$
\mathrm{IPP}=\gamma_{0}+\gamma_{1} \sigma_{1}+\gamma_{2}(\mathrm{~B} / \mathrm{V})+\varepsilon_{1}
$$

In this equation, $\mathrm{B}$ is the face value of deposits and other debt, $\mathrm{V}$ is the market value of a bank's assets, $\sigma_{\mathrm{V}}$ is the standard deviation of asset returns, and IPP is the "fair" deposit insurance premium per dollar of deposits.

Duan, Moreau, and Sealey (1992) show that we can assess bank-risk shifting incentives by breaking out the following pair of equations:

$$
\begin{gathered}
\mathrm{B} / \mathrm{V}=\alpha_{0}+\alpha_{1} \sigma_{\mathrm{V}}+\varepsilon_{2}, \\
\mathrm{IPP}=\beta_{0}+\beta_{1} \sigma_{\mathrm{V}}+\varepsilon_{3} .
\end{gathered}
$$


The intuition is that of a rational-expectations game: a bank sets its leverage and asset risk, $\sigma_{\mathrm{V}}$, with a clear understanding that creditors and regulators will monitor and discipline their choices. Similarly, creditors and regulators expect banks to react to the discipline they provide. Equation (2) expresses the idea that regulators and creditors constrain banks to a limited set of leverage and volatility pairs. The slope coefficients in equations (2) and (3) have the following interpretations:

$$
\begin{gathered}
\alpha_{1} \equiv \frac{d(B / V)}{d \sigma_{V}} \\
\beta_{1} \equiv \frac{\partial I P P}{\partial \sigma_{V}}+\frac{\partial I P P}{\partial(B / V)} \alpha_{1}=\gamma_{1}+\gamma_{2} \alpha_{1} .
\end{gathered}
$$

The Merton model (1) treats the insurer's guarantee as a simple put option that the bank sells on its assets. This formulation implies that, other things equal, the value of deposit insurance increases in both $\sigma_{V}$ and $B / V$. By themselves, the positive partial derivatives $\gamma_{1}=\partial I P P / \partial \sigma_{V}$ and $\gamma_{2}=\partial I P P / \partial(B / V)$ in the linearized model (1) tell us how much value bank stockholders might extract from the insurer by marginal adjustments. However, in practice, the deposit-insurance contract conveys loss-control powers to the put holder that permit an insurer to monitor and control risk taking by client banks.

If effective, risk-sensitive capital requirements modify what we can call the utility value of risk-taking by introducing penalties that create a negative relationship between $B / V$ and $\sigma_{V}$. Hence, the values of $\alpha_{1}$ and $\beta_{1}$ indicate whether regulatory and market discipline forces a bank to strengthen its capital position as its asset volatility increases and to cut back its volatility when its leverage increases. A negative $\alpha_{1}$ would imply that 
risk-sensitive capital regulation and complementary market discipline constrain realizable deposit-insurance benefits.

Given the external discipline a bank faces, Equation (3) measures whether asset volatility influences on balance the value of the implicit and explicit government guarantees that are imbedded in the bank's stock price. To fully neutralize risk-shifting incentives at the margin, disciplinary penalties that induce a decline in $B / V$ must be large enough to fully offset whatever increase in $I P P$ would otherwise be generated by a higher $\sigma_{V}$. Empirically, if the total derivative $\beta_{l}$ is nonpositive, risk-shifting incentives are fully neutralized.

Thus, for market and regulatory pressure to consistently discipline and potentially neutralize incremental risk-shifting incentives, two conditions must be met:

Capital increases with volatility: $\quad \alpha_{1}<0$,

Guarantee value does not rise with volatility: $\quad \beta_{1} \leq 0$.

None of the variables featured in our three equations is directly observable. However, Marcus and Shaked (1984) show how to use option-based models of deposit insurance to track these variables synthetically. Because unobservable expectations play a central role in term-structure and asset-pricing theories, running regressions on synthetic data sets is a common practice in finance. Our two-step econometric models test substantive hypotheses about asset valuation jointly with the subsidiary hypothesis that the synthetic observations are unbiased estimates of the true variables. In our experiments, one cannot rule out the possibility that measurement error and simultaneous-equation bias distort our results. Murphy and Topel (1985) show that standard errors of substantive parameters are often underestimated in two-step tests. 
These considerations suggest that we should interpret t-values conservatively and subject our results to a variety of robustness tests.

The first step in the Marcus-Shaked procedure is to obtain tracking values for $\mathrm{V}$ and $\sigma_{\mathrm{V}}$ by numerical methods. These values are then used to estimate IPP as the value of a put option on bank assets. The procedure begins by solving the call-option formula for equity, E. The last step uses Itto's lemma to link $\sigma_{\mathrm{V}}$ to $\mathrm{E}, \mathrm{V}$ and $\sigma_{\mathrm{E}}$ (the instantaneous standard deviation of equity returns) by means of equation (6):

$$
\sigma_{\mathrm{V}}=\sigma_{\mathrm{E}}(\mathrm{E} / \mathrm{V}) /(\partial \mathrm{E} / \partial \mathrm{V}) .
$$

To establish whether inferences are robust to differences in how forbearance is modeled, we conducted regressions using proxies for $\mathrm{V}, \sigma_{\mathrm{V}}$, and IPP derived from three different models of deposit-insurance option value. ${ }^{1}$

The first model follows Merton (1977) in portraying deposit insurance as a singleperiod European put option on the bank's assets. This model treats bank equity as the sum of a dividend-unprotected European call option and the present value of the dividends distributed before the option's expiration date. The bank's debt is assumed to mature in one year, which is also the assumed exercise date for the insurer. The model expresses the value of a bank's equity, $E$, and the value of the fair deposit insurance premium, $I P P$, as:

$$
\begin{gathered}
\mathrm{E}=\mathrm{V}\left[1-(1-\delta)^{\mathrm{T}}\right]+\mathrm{V}(1-\delta)^{\mathrm{T}} \mathrm{N}\left(\mathrm{x}_{1}\right)-\mathrm{BN}\left(\mathrm{x}_{2}\right), \\
\mathrm{IPP}=\mathrm{N}\left(-\mathrm{x}_{2}\right)-(1-\delta)^{\mathrm{T}} \mathrm{N}\left(-\mathrm{x}_{1}\right) \mathrm{V} / \mathrm{B} .
\end{gathered}
$$

In (7) and (8), $\delta$ is the fraction of bank assets distributed at each interim dividend date to stockholders, $\mathrm{T}$ is the number of interim dividend payments, $\mathrm{N}\left(\mathrm{x}_{\mathrm{i}}\right)$ states the probability 
that the variate value $\mathrm{x}$ is $\leq \mathrm{x}_{\mathrm{i}}$, given that $\mathrm{x}$ is distributed with zero mean and unit variance. $^{2}$

Ronn and Verma (1986) adapt Merton's model to account for market conjectures that the FDIC may forbear from exercising its implicit call on the put when its claim is only slightly in the money. The RV model scales down the effective exercise price of the put by a factor of $\rho=0.97$. Our second model employs an adaptation of the RV model devised by Hovakimian and Kane (2000):

$$
\begin{gathered}
\mathrm{E}=\mathrm{V}\left[1-(1-\delta)^{\mathrm{T}}\right]+\mathrm{V}(1-\delta)^{\mathrm{T}} \mathrm{N}\left(\mathrm{x}_{3}\right)-\rho \mathrm{BN}\left(\mathrm{x}_{4}\right), \\
\mathrm{IPP}=\mathrm{N}\left(-\mathrm{x}_{4}\right)-(1-\delta)^{\mathrm{T}} \mathrm{N}\left(-\mathrm{x}_{3}\right) \mathrm{V} / \mathrm{B} .
\end{gathered}
$$

The third model also appears in Hovakimian and Kane (2000). It assigns stockholder benefits from forbearance only to banks that actually experience a capital shortfall. This model suppresses the forbearance benefit $(1-\rho) \mathrm{BN}\left(\mathrm{x}_{2}\right)$ for solvent banks. The value of a bank's equity becomes:

$$
\begin{gathered}
E=V\left[1-(1-\delta)^{\mathrm{T}}\right]+V(1-\delta)^{\mathrm{T}} \mathrm{N}\left(\mathrm{x}_{3}\right)-\rho \mathrm{BN}\left(\mathrm{x}_{4}\right)-(1-\rho) \mathrm{BN}\left(\mathrm{x}_{2}\right), \\
I P P=N\left(-\mathrm{x}_{4}\right)-(1-\delta)^{\mathrm{T}} \mathrm{N}\left(-\mathrm{x}_{3}\right) \mathrm{V} / \mathrm{B}-(1-\rho) \mathrm{N}\left(\mathrm{x}_{2}\right) .
\end{gathered}
$$

These models fix $\rho$ at either 1.0 or 0.97 for every country at every date. Although one might usefully experiment with other specifications, the policy implications of our regression tests prove relatively insensitive to this parameter.

Pennacchi (1987a and b) shows that, by counterfactually presuming prompt and complete insolvency resolution, single-period models of IPP tend to understate the economic value that government guarantees convey to bank stockholders. In exploring

\footnotetext{
${ }^{1}$ Hovakimian and Kane (2000) provide a detailed discussion of these models.
} 
risk-shifting opportunities and authorities' ability to control them, this bias promises to increase the power of regression tests based on Merton's minimal-forbearance model.

\section{Sample Selection and Data}

The paper uses annual data from 1991 through 1999. Bank-level data come from two sources. Monthly stock prices and annual market values of equity are obtained from Datastream. Balance-sheet data come from Bankscope. ${ }^{3}$ Data on incentive-modifying deposit insurance features employed in different countries come from the World Bank Survey of Prudential Regulations and Supervision of Commercial Banks and from the Demirgüç-Kunt and Sobaci (2001) database studied by Demirgüç-Kunt and Kane (2002).

Country characteristics are measured on three dimensions. Repression of political rights and civil liberties is measured by the Freedom House, which constructs a categorical repression indicator. ${ }^{4}$ This indicator recognizes three categories: free, partly free, and not free. The second index is a measure of economic freedom compiled by the Heritage Foundation. ${ }^{5}$ The third index reports the perceived corruption of national governments $(\mathrm{CP})$ as assessed by Transparency International. ${ }^{6}$ This index ranks countries on a scale of 1 (very corrupt) to 10 (not corrupt). The $\mathrm{CP}$ is based on surveys of

${ }^{2} \mathrm{x}_{1}=\left[\ln \left((1-\delta)^{\mathrm{T}} \mathrm{V} / \mathrm{B}\right)+\sigma_{\mathrm{V}}{ }^{2} \mathrm{~T} / 2\right] /\left(\sigma_{\mathrm{V}} \sqrt{ } \mathrm{T}\right), \mathrm{x}_{2}=\mathrm{x}_{1}-\sigma_{\mathrm{V}} \sqrt{\mathrm{T}}, \mathrm{x}_{3}=\left[\ln \left((1-\delta)^{\mathrm{T}} \mathrm{V} / \rho \mathrm{B}\right)+\sigma_{\mathrm{V}}{ }^{2} \mathrm{~T} / 2\right] /\left(\sigma_{\mathrm{V}} \sqrt{ } \mathrm{T}\right), \mathrm{x}_{4}=\mathrm{x}_{3}-$ $\sigma_{\mathrm{V}} \sqrt{\mathrm{T}}$.

${ }^{3}$ To scale down the number of listed banks in Japan and the US, we include only long-term credit, city and trust banks in Japan and in the U.S. only multinational and superregional banks as these are defined by Goldman Sachs in its Global Banks Fact Sheet (July 2000).

${ }^{4}$ These data are explained at the following website: $\mathrm{http}: / / \mathrm{www}$.freedomhouse.org.

${ }^{5}$ The economic freedom index tracks the following factors: Corruption in the judiciary, customs service, and government bureaucracy; Non-tariff barriers to trade, such as import bans and quotas as well as strict labeling and licensing requirements; The fiscal burden of government, which encompasses income tax rates, corporate tax rates, and government expenditures as a percent of output; The rule of law, efficiency within the judiciary, and the ability to enforce contracts; Regulatory burdens on business, including health, safety, and environmental regulation; Restrictions on banks regarding financial services, such as selling securities and insurance; Labor market regulations, such as established work weeks and mandatory 
business people, academics, and risk analysts. Because the three indices measure related aspects of a country's institutional infrastructure, pairwise correlations among the indices range between 0.54 and 0.67. Panel A of Table I summarizes the distribution of each index and selected deposit-insurance features across sample countries.

Individual-bank data were screened in two ways. First, to be included into our sample, the datasets must record at least three years of data on the input variables needed to calculate $\mathrm{B} / \mathrm{V}, \sigma_{\mathrm{V}}$, and IPP. Second, to guard against reporting errors in the Datastream source, observations generating extreme values for these variables (i.e., below the first or above the ninety-ninth percentiles) are trimmed away. These screening criteria are satisfied for a total of 2,255 bank-year observations. The political freedom indicator is available for 2,192 observations. The economic freedom index is available for 1,533 observations. The $\mathrm{CP}$ is available for 1,401 observations.

Panel B in Table I summarizes sample coverage by country, year, and deposit insurance status. Our sample covers 390 banks representing 56 countries. The number of observations per country varies from four (one bank) for Russia to 309 (42 banks) for Denmark. Ten countries (299 observations) limit themselves to implicit deposit insurance during our observation period. Eight more countries (351 observations) introduce explicit deposit insurance (EI) during the period. The remaining thirty-eight countries (1605 observations) offer explicit insurance throughout the observation period.

For four salient subsamples, Table II reports the mean leverage ratio, the standard deviation of returns on assets, and the mean insurance premium per dollar of deposits

\footnotetext{
separation pay; and Black market activities, including smuggling, piracy of intellectual property rights, and the underground provision of labor and other services.

${ }^{6}$ Additional details may be found at http://www.transparency.org.
} 
calculated from the three alternative models of deposit insurance summarized in Section I. The first column reports values for observations recorded under an implicit insurance (II) regime. These estimates pool observations from countries that never introduced explicit guarantees with pre-adoption observations for countries that introduced EI during our 1991-99 observation period. Column (2) pools all observations in years spent under an EI regime.

Standard t-tests indicate that the EI subsample is characterized by significantly higher leverage but significantly lower return volatility. Although mean IPP proves lower in the EI subsample, the differences in leverage and volatility broadly offset each other, so that the difference in premiums is not statistically significant. For each subsample, the mean values of leverage and return volatility vary only slightly across the three models. However, the economic significance of the observed difference in leverage emerges clearly if the fraction reported is inverted. How forbearance is modelled proves important in that the mean IPP varies directly with the degree of forbearance assumed.

Demirgüç-Kunt and Kane (2002) argue that many of the countries that adopted deposit insurance in the 1990s lacked an appropriate institutional infrastructure and were unable to compensate for imperfections in their contracting environments. For the subset of countries that introduced EI during the observation period, columns (3) and (4) in Table II compare results experienced under implicit and explicit regimes. The explicitregime subsample shows a significantly higher leverage ratio (9.2 vs. 8.3) and an insignificantly higher return volatility. However, fair deposit insurance premiums are significantly higher under the EI regimes than under the preceding implicit regimes. For countries introducing EI during the 1990s, not only does the leverage ratio increase from 
8.6 to 11.6 , but banks show an increase rather than a decrease in return volatility and a substantially (and significantly) higher mean IPP. This indicates that regulatory discipline did a poor job of replacing the bank bonding activities and depositor discipline that EI displaced.

Table III reports the mean value of the fair explicit premium for banks in each sample country under each of the models summarized in Section I. For each country, the value of government guarantees increases with the degree of forbearance assumed. Values range from less than 0.001 percent for Australia, Austria, Germany, and Luxembourg using Merton's minimal-forbearance model to a high of 2.943 percent for Russia using RV's maximal-forbearance formulation. Particularly large values are reported for countries known to have experienced a financial crisis during the observation period.

\section{The Effects of Deposit Insurance on Risk-Shifting Behavior}

\section{A. Benchmark Runs}

In this section, we examine the effectiveness of risk-shifting controls by expanding models (1) through (3) to include bank-specific fixed effects and particular deposit-insurance design features. Likelihood-ratio and Hausman tests support the fixedeffects specification over either a random-effects specification or a specification that dispenses with bank-specific effects. Because the Merton and Hovakimian-Kane models achieve much the same results, we report benchmark estimates for the Merton and RonnVerma specifications only. 
Tables IV and V let us compare results for four versions of regressions (1) through (3). In each table, results for a fixed-effects benchmark model appear in the first column of Panels A, B, and C. Each panel explores a different question:

A. How valuable are unconstrained increases in leverage and volatility?

B. How strongly do capital requirements discipline volatility?

C. Do officials generate enough supervisory and regulatory pressure to offset the private bonding and depositor discipline that government guarantees displace?

Panel A summarizes the benefits of unconstrained risk-shifting. However, the significantly negative estimates for $\alpha_{1}$ in Panel B confirm that, on balance across the sample, regulatory capital requirements and private market pressure did generate riskrestraining discipline. Unfortunately, the significantly positive $\beta_{1}$ value in the first column of Panel $\mathrm{C}$ tells a sadder story. It implies that on average outside restraints on bank risk-taking did not fully neutralize risk-shifting incentives.

Column (2) minimally expands the fixed-effects regressions. It introduces a zeroone dummy variable to recognize the presence of explicit insurance: the "EI Dummy." In both tables, the EI dummy receives a negative sign in the Panel A regressions, indicating that on average explicit insurance did not increase risk-shifting opportunities. However, the significantly positive values found for EI as a slope-shift parameter in the Panel B $(\mathrm{B} / \mathrm{V})$ regressions indicate that net external discipline declines. Apparently, explicit deposit insurance displaces more private policing than authorities manage to supply. In the Panel C (restrained IPP) regressions, the effect of explicit deposit insurance on risk shifting is insignificant in both Tables IV and V. Still, it is only in the minimal- 
forbearance Merton model (Table IV) that the coefficient on the EI dummy in the IPP regression even receives the hoped-for negative sign.

Columns (3) and (4) further expand the regressions to allow risk-mitigating features of deposit-insurance design also to influence model coefficients. The first experiment interacts a dummy variable that is set to one if explicit premiums are risksensitive, and is zero otherwise. The regression experiments reported in column (4) look at two additional interactions. These experiments introduce dummy variables for the existence of coinsurance and limits on the size of insured balances. The results show that the strength of risk-shifting incentives depends critically on deposit insurance design. In both the leverage and the constrained IPP regressions, coefficient estimates for the explicit insurance dummy are significantly positive, but coefficient estimates for all three interacted risk-control features prove significantly negative. This indicates that contractual controls designed to reduce bank risk-shifting incentives are at least partially successful.

The differences observed are economically significant. For example, column (4) of Panel C of Table IV indicates that a percentage-point increase in asset volatility $\sigma_{\mathrm{V}}$ generates a 16 basis-point increase in IPP in countries without EI and a 23 basis-point increase in countries that adopt EI but refrain from introducing any risk-mitigating design features. On average, increases in $\sigma_{\mathrm{V}}$ slightly reduce IPP in countries that adopt all three risk-mitigating features.

\section{B. How does risk-shifting change when a country adopts explicit insurance?}

The insignificance of the interacted EI Dummy in column (2) of the IPP regressions in Tables IV and V may reflect differences in economic and political maturity 
between countries that adopted EI years ago and those that adopted it only recently. In this subsection, we focus on the subsample of 351 observations drawn from countries that installed explicit insurance during 1991-99. The analysis seeks to assess the quality of risk control in these countries in terms of shifts in $\alpha_{1}$ and $\beta_{1}$ observed in the post-adoption era.

Comparing Panel A of Table VI with the same panel of Table IV shows that unconstrained risk-shifting offers larger returns in adopting countries, while the last column shows that explicit insurance reduced IPP only in countries that set coverage limits. In the Panel B and C regressions, significantly positive coefficients emerge for the interacted variable (EI Dummy $\times \sigma_{\mathrm{V}}$ ). This result confirms that regulators in other adopting countries were unable to compensate adequately for the private monitoring that EI displaced. The favorable effect of the Risk-Sensitive Premium Dummy in containing risk-shifting incentives fails to achieve significance in Table VI. However, the slopeshift estimated for the Coverage Limits Dummy remains significantly negative in all regressions. $^{7}$

\section{How risk-shifting is affected by specific country characteristics}

\section{A. Differences in Risk-Shifting Across Environments}

In countries where political and economic freedoms are low and government corruption is high, households and firms should be reluctant to entrust their deposits to opaque banks. In these circumstances, agents that become depositors are apt to insist on information flows, bonding activity, and deterrent rights sufficient to price the risk 
exposure banks pass through to them. Kane (2000) argues that, in low freedom/high corruption countries, introducing explicit deposit insurance is apt to displace more private discipline than government regulators may reasonably be expected to generate in its stead.

Tables VII through IX test this hypothesis with data derived from the Merton model. ${ }^{8}$ The tests investigate the extent to which coefficients of our three equations differ across subsamples of countries whose institutional environments differ in specified ways. In each table, observations have been ranked and grouped into subsamples according to the strength of a particular measure of the character of a country's financial contracting environment. Each experiment is limited to countries for which the particular measure is available. In every panel, we benchmark the risk-shifting opportunities that exist in the absence of explicit insurance, and use the EI dummy to estimate the adjustment in opportunities occurring in countries that have adopted EI.

Table VII investigates the effect of differences in political freedom using a threeway partition developed by Freedom House. Because this index is widely available, this experiment includes almost every observation studied in Tables IV and V. Panel A shows that, as freedom declines, risk-shifting opportunities increase. The leverage regressions in Panel B indicate that, as freedom declines, private discipline tends to increase and so does the extent to which it is displaced by EI. The Panel C regressions indicate that risk-shifting opportunities exist even without EI, except in the economies that show the least amount of political freedom. Again, the perverse effect of introducing EI grows as freedom declines.

\footnotetext{
${ }^{7}$ The Coinsurance Dummy could not be incorporated into these runs because no country in the recent-
} 
Table VIII partitions the 1533 observations for which the Economic Freedom index exists. The "free" subsample includes all countries whose score on the index equaled or exceeded the median value of 2.3. Results differ sharply between the two environments. In strong (i.e., "free") contracting environments, explicit insurance strengthens rather than undermines private risk-shifting discipline. However, and as we found in Table VII, in poor contracting environments, EI expands banks' opportunities to shift risk.

Table IX examines the 1401 observations covered by the Corruption index. Kane (2000) shows that in countries for which accounting standards have been indexed, the CP correlates strongly with the informativeness of accounting records. $\mathrm{CP}$ may also correlate positively with a government's capacity to collect taxes. Countries are divided according to whether $\mathrm{CP}$ falls short of or exceeds 5 , the midpoint of the index range. In both regressions, benchmark discipline is greater in more-corrupt and less-transparent environments, and explicit insurance expands risk-shifting opportunities in highcorruption environments. In low-corruption countries, while EI exerts no significant effect on leverage discipline, its presence does serve to limit the size of the fair insurance premium.

That explicit insurance arrangements control risk-shifting only in strong contracting environments accords with empirical evidence on how explicit insurance affects the probability of financial crisis as summarized in Demirgüç-Kunt and Kane (2002). Tables VII to IX support these authors' contention that governments should repair weaknesses in their contracting environments before trying to establish an explicit 
deposit insurance system. The differences we observe continue to be economically significant. For example, in Panel C of Table IX, a percentage-point increase in asset volatility $\sigma_{\mathrm{V}}$ generates a net 16 basis-point increase in corrupt countries, but only a 10 basis-point increase in IPP in countries that are less corrupt.

\section{B. Robustness Tests Focusing on Equations (2) and (3)}

Our final experiments expand in sometimes-complicated ways the regressions reported in the previous six tables. Both to save space and to focus the robustness testing on policy implications, Table X through XIII omit parallel results for adapted versions of Equation (1).

Table $\mathrm{X}$ investigates whether we can incorporate deposit-insurance design features and potentially collinear country characteristics into summary regressions. In both the leverage and IPP equations, results confirm the patterns found for individual depositinsurance features in Tables IV to VI. However, the disruptions we observe in coefficient magnitudes from specification to specification support the hypothesis that unfavorable country characteristics adversely influence deposit-insurance design.

Because the coverage of individual indices must overlap, the final catchall regressions must be run over a particularly small subsample. The catchall IPP regression implies that when we control for levels of political repression, corruption, and restrictions on economic freedom at the same time, EI strongly expands risk-shifting and coinsurance and coverage limits significantly reduce it. While economic freedom drops out of the catchall fair-premium regression, political repression promotes benchmark risk-shifting and integrity in government curtails it.

\footnotetext{
${ }^{8}$ The results (not reported) are qualitatively similar when the other two models are used.
} 
Two-step regression model with self-selection. It seems likely that the coefficient estimates found for deposit insurance design features in Tables IV and V are subject to sample-selection bias. Countries that adopt features to restrain risk-shifting behavior might have experienced less risk-shifting in any case, precisely because the overall contracting environment in these countries restrains risk shifting. As a robustness check, we re-estimate the coefficients for design features using Heckman's $(1976,1978)$ twostep approach to incorporate control-system self-selection. The endogenous variable in the first-stage probit model is a dummy variable that indicates whether the design feature is selected or not. We investigate three features: risk-sensitive premiums, coinsurance, and coverage limits. The results of the second-stage model are presented in Table XI. Because Heckman's method reduces the useable sample we also report OLS estimates for the original model using the parallel subsample. ${ }^{9}$ The coefficient for Heckman's lambda (also known as the inverse Mill's ratio) measures the covariance of the error terms from the substantive regression and the selection equation. A significant coefficient on Heckman's lambda indicates the presence of a sample-selection bias.

The results support the hypothesis of sample-selection bias, since the coefficient on Heckman's lambda is significant in all but one specification. However, taking account of selection affects only one policy implication: risk-sensitive premiums lose statistical significance in the IPP regression. However, the sample size in these runs is less than half of that employed in Table IV. Because this increases the standard error of each test, it makes it harder to reject the null.

\footnotetext{
${ }^{9}$ The sample size is smaller because the first-stage probit is estimated for observations with non-missing values of the indices of political freedom, economic freedom, and corruption.
} 
Switching Regression Model with Unknown Sample Separation. This section uses a switching regression model with unknown sample separation (Maddala, 1983) to test the hypothesis that risk-shifting incentives vary with the strength of a country's institutional environment. The switching model has three equations: ${ }^{10}$

$$
\begin{gathered}
B / V_{1}=\alpha_{1}^{0}+\alpha_{1}^{1} \sigma_{V}+\varepsilon_{1}, \\
B / V_{2}=\alpha_{2}^{0}+\alpha_{2}^{1} \sigma_{V}+\varepsilon_{2}, \\
I^{*}=Z \gamma+u .
\end{gathered}
$$

Equations (12) and (13) are risk-control equations that characterize the behavior of banks in the alternate regimes. Equation (14) is a control-system selection equation. It expresses a bank's latent qualifications, $I^{*}$, to follow one or the other regime. $I^{*}$ is specified to be a function of our three proxies for the quality of the institutional environment. The sign of $I^{*}$ determines whether either $B / V_{l}$ or $B / V_{2}$ is observed:

$$
\begin{aligned}
& B / V_{i t}=B / V_{\text {lit }} \text { iff } I_{\text {it }}{ }^{*}<0 \\
& B / V_{i t}=B / V_{2 i t} \text { iff } I_{i t}{ }^{*} \geq 0 .
\end{aligned}
$$

This switching regression model offers three advantages. First, it estimates differences in risk-shifting behavior endogenously, without having to specify in advance either what regime applies to each bank or the value of the sample breakpoint. Second, this model can investigate the individual and joint influence of several determinants of regime character. Because environmental characteristics jointly govern sample selection, the model incorporates more information into the process of separating risk-control regimes. Third, the model can assess the relative importance of our three proxies for institutional strength.

${ }^{10}$ Three parallel equations are specified for the fair deposit insurance premiums, IPP. 
Table XII estimates the switching model for leverage control, while Table XIII reports parallel estimates for risk shifting. Panel A reports the selection equations and Panels B and C present the alternate risk-control models. The coefficients reported in these tables are estimated by Maximum Likelihood. The likelihood function is as follows: ${ }^{11}$

$$
L=\Phi\left(-Z_{i t} \gamma\right) \phi\left(\varepsilon_{1 i t}\right)+\left[1-\Phi\left(-Z_{i t} \gamma\right)\right] \phi\left(\varepsilon_{2 i t}\right)
$$

where $\phi($.$) is the density function and \Phi($.$) is the cumulative of the normal distribution.$

The selection equations model institutional strength more plausibly than the catchall leverage and premium regressions presented in Table X. Every country characteristic receives the same sign in both equations. Political repression and corruption weaken the public contracting environment. Although economic repression is found to strengthen controls on bank leverage, its effect on net risk shifting is less strongly significant.

The risk-control equations confirm our previous findings. In weak contracting environments, background controls on private contracting are stronger, and introducing explicit insurance significantly undermines environmental controls. In strong environments, explicit insurance improves leverage control though, on balance, the extent of risk shifting does not change significantly.

Regression Results by Geographic Region. As a final sensitivity test, we estimate the parsimonious risk-control equations featured in Tables XII and XIII for each of nine broad geographic regions. Of course, in any region where all member countries either do

\footnotetext{
${ }^{11}$ Shocks to leverage, $\mathrm{B} / \mathrm{V}$, and the shocks to the institutional environment are assumed to be uncorrelated. Attempts to estimate models that allow correlated errors in the risk-controls and the selection equations
} 
or do not offer explicit insurance, a slope-shift term for EI cannot be estimated. Table XIV reports the results.

Except between Eastern Europe and Latin America, leverage and risk-shifting coefficients vary significantly across all possible regional pairings. Leverage and riskshifting control systems appear particularly strong in Australia (which has eschewed explicit insurance) and North America. Although leverage discipline is exerted on balance in every region, risk-shifting opportunities vary substantially. The coefficients for fair premiums are particularly high in Asia and Africa. Countries that have adopted explicit insurance systems in Eastern Europe, Latin America, and the Middle East appear to have managed to restrain risk-shifting incentives, but Western European countries with explicit insurance have intensified risk-shifting opportunities to some extent. However, some of the regional differences turn on some very small samples. For example, the subsample of Eastern European banks with no explicit deposit insurance consists of four observations derived from a single Russian bank. The subsample of Western European banks with no explicit deposit insurance consists of two observations of Greek banks and seven observations of Swedish banks. Therefore, the effect of explicit deposit insurance in Western Europe may be driven by relatively low risk-shifting in Sweden.

In the fair premium regressions, the $\sigma_{\mathrm{v}}$ coefficient may be interpreted as a measure of the strength of implicit guarantees. On this reading, expectations of depositor bailouts are extremely high in Eastern Europe and Latin America and moderately high in Asia and Africa.

\section{Summary and Conclusions}

encountered convergence problems. 
Modern finance theory stresses that depositors and other creditors must mitigate incentives for opportunistic behavior by bank managers, owners, and borrowers. To bond their willingness to behave nonopportunistically, banks must convey to depositors a degree of informational transparency and an appropriate set of deterrent rights. Because individual efforts to monitor and police bank risk-taking exhibit wasteful overlaps, efficiency demands that depositor oversight be supplemented by some centralized program of monitoring and control. This centralized program must be able to establish, enforce, and dynamically readjust protocols for verification, disclosure, truth-telling, promise-making, promise-keeping, and conciliation.

In practice, risk-control protocols are imbedded in a financial safety net erected and managed by government officials. The ideal safety net is one that efficiently mitigates the particular monitoring and policing difficulties that present themselves in the contracting environment of a given country. These difficulties are apt to vary with informational, ethical, legal, and economic subcultures that govern the design and enforcement of financial contracts.

Public-choice theory recognizes that officials' incentives differ in important ways from those of private creditors. To persuade safety-net managers to make socially optimal choices, taxpayers must be able to observe and protect their stake in regulatory activities.

This paper investigates how well authorities in 56 different countries have restrained bank risk-shifting incentives in recent years. Results show that the effectiveness of private and governmental controls on bank leverage and depositinsurance subsidies varies across contracting environments in predictable ways. 
In any country, explicit deposit insurance threatens to displace more private discipline than official oversight can generate. In strong contracting environments, officials usually manage to avoid this result. Significant portions of the variation in the effectiveness of risk control are explained by differences in political climate, economic freedom, and government corruption. Regressions incorporating these environmental factors are sensitive to model specification, but they indicate on balance that explicit deposit insurance expands risk-shifting opportunities in poor contracting environments.

Our data show that the displacement of private discipline is reduced in systems that impose appropriate combinations of loss-sharing rules, risk-sensitive premiums, and coverage limits. Unfortunately, in poor contracting environments, explicit deposit insurance has an unhealthy appeal to policymakers. Regression results confirm that recent adopters of explicit insurance have done a particularly poor job of replacing the depositor discipline that explicit insurance displaced.

Two important lessons follow. First, weaknesses in risk control can generate large fiscal and social costs under an explicit insurance regime, a truth that most recent financial crises underscore (Honohan and Klingebiel, 2002). Because the effectiveness of risk control depends on deposit insurance design and country circumstances, in the long run adopting explicit insurance can easily do more harm than good. Countries with a poor contracting environment should upgrade this environment before adopting explicit deposit insurance. Second, even in a good contracting environment, the benefits of explicit deposit insurance depend critically on safety-net design. Risk-mitigating features such as risk-based premiums, coinsurance and low coverage levels can curb bank risk- 
shifting. However, countries where government corruption is high and economic and political freedom is low find it difficult to adopt and enforce appropriate restraints. 


\section{References}

Allen, L. and A. Saunders, 1993, Forbearance and valuation of deposit insurance as a callable put, Journal of Banking and Finance 17, 629-643.

Brickley, J.A. and C.M. James, 1986, Access to deposit insurance, insolvency rules, and the stock returns of financial institutions, Journal of Financial Economics 16, 345 372 .

Buser, S.A., A.H. Chen and E.J. Kane, 1981, Federal deposit insurance, regulatory policy, and optimal bank capital, Journal of Finance 35, 51-60.

Calomiris, C.W., 1992, Getting the incentives right in the current deposit-insurance system: successes from the pre-FDIC era, in J.R. Barth and R.D. Brumbaugh, Jr., eds.: The reform of federal deposit insurance: Disciplining government and protecting taxpayers (Harper Collins, New York), 13-35.

Demirgüç-Kunt, A. and E. Detragiache, 2002, Does deposit insurance increase banking system stability? An empirical investigation, Journal of Monetary Economics, forthcoming.

Demirgüç-Kunt, A. and H. Huizinga, 1999, Market discipline and financial safety net design, Policy research working paper No. 2183, World Bank.

Demirgüç-Kunt, A., and E.J. Kane, 2002, Deposit insurance around the world: where does it work?, Journal of Economic Perspectives, 16 (Spring), pp. 175-195.

Demirgüç-Kunt, A. and T. Sobaci, 2001, A new development database. Deposit insurance around the world, World Bank Economic Review 15, 481-490.

Duan, J-C., A.F. Moreau and C.W. Sealey, 1992, Fixed-rate deposit insurance and riskshifting behavior at commercial banks, Journal of Banking and Finance 16, 715-742.

Heckman, J., 1976, The common structure of statistical models of truncation, sample selection and limited dependent variables and a simple estimator for such models, Annals of Economic and Social Measurement 5, 475-492.

Heckman, J., 1978, Dummy endogenous variables in a simultaneous equation system, Econometrica 46, 931-959.

Honohan, P., and D. Klingebiel, 2002, The fiscal cost implications of an accommodating approach to banking crises, Journal of Banking and Finance, forthcoming.

Hovakimian A., and E.J. Kane, 2000, Effectiveness of capital regulation at U.S. commercial banks, 1985-1994, Journal of Finance 55, 451-469.

Kane, E.J., 1995, Three paradigms for the role of capitalization requirements in insured financial institutions, Journal of Banking and Finance 19, 431-454. 
Kane, E.J., 2000, Designing financial safety nets to fit country circumstances, Mimeo, Boston College.

Laeven, L., 2002a, Bank risk and deposit insurance, World Bank Economic Review, 16, pp. 109-137.

Laeven, L., 2002b, International evidence on the cost of deposit insurance, Quarterly Review of Economics and Finance, 42, pp. 721-732.

Madalla, G.S., 1983. Limited-Dependent and Qualitative Variables in Econometrics, New York: Cambridge University Press.

Marcus, A.J., 1984, Deregulation and bank financial policy, Journal of Banking and Finance 8, 557-565.

Marcus, A.J., and I. Shaked, 1984, The valuation of FDIC deposit insurance using option-pricing estimates, Journal of Money, Credit, and Banking 16, 446 - 460.

Merton, R.C., 1977, An analytic derivation of the cost of deposit insurance and loan guarantees, Journal of Banking and Finance 1, 3-11.

Merton, R.C., 1978, On the cost of deposit insurance when there are surveillance costs, Journal of Business 51, 439-452.

Murphy, K.M., and R.H. Topel, 1985. Estimation and Inference in Two-Step Econometric Models, Journal of Business \& Economic Statistics, 3, 370-379.

Pennacchi, G.G., 1987a, A reexamination of the over- (or under-) pricing of deposit insurance, Journal of Money, Credit, and Banking 19, 340-360.

Pennacchi, G.G., 1987b, Alternative forms of deposit insurance: pricing and bank incentive issues, Journal of Banking and Finance 11, 291-312.

Ronn, E.I. and A.K. Verma, 1986, Pricing risk-adjusted deposit insurance: An optionbased model, Journal of Finance 41, 871 - 895. 


\section{Table I}

Panel A: Distribution of country-level variables

\begin{tabular}{lccccc}
\hline & Mean & Median & Minimum & Maximum & Obs. \\
\hline Explicit Insurance Dummy & 0.78 & 1 & 0 & 1 & 2255 \\
Risk-Sensitive EI Dummy & 0.21 & 0 & 0 & 1 & 1760 \\
Coinsurance Dummy & 0.15 & 0 & 0 & 1 & 1760 \\
Coverage Limits Dummy & 0.72 & 1 & 0 & 1 & 1486 \\
Political Freedom Index & 1.28 & 1 & 1 & 3 & 2192 \\
Economic Freedom Index & 2.39 & 2.3 & 1.3 & 4 & 1533 \\
Corruption Index & 6.44 & 6.7 & 1 & 10 & 1401 \\
\hline
\end{tabular}

Panel B: Sample composition by country, year, and deposit insurance status

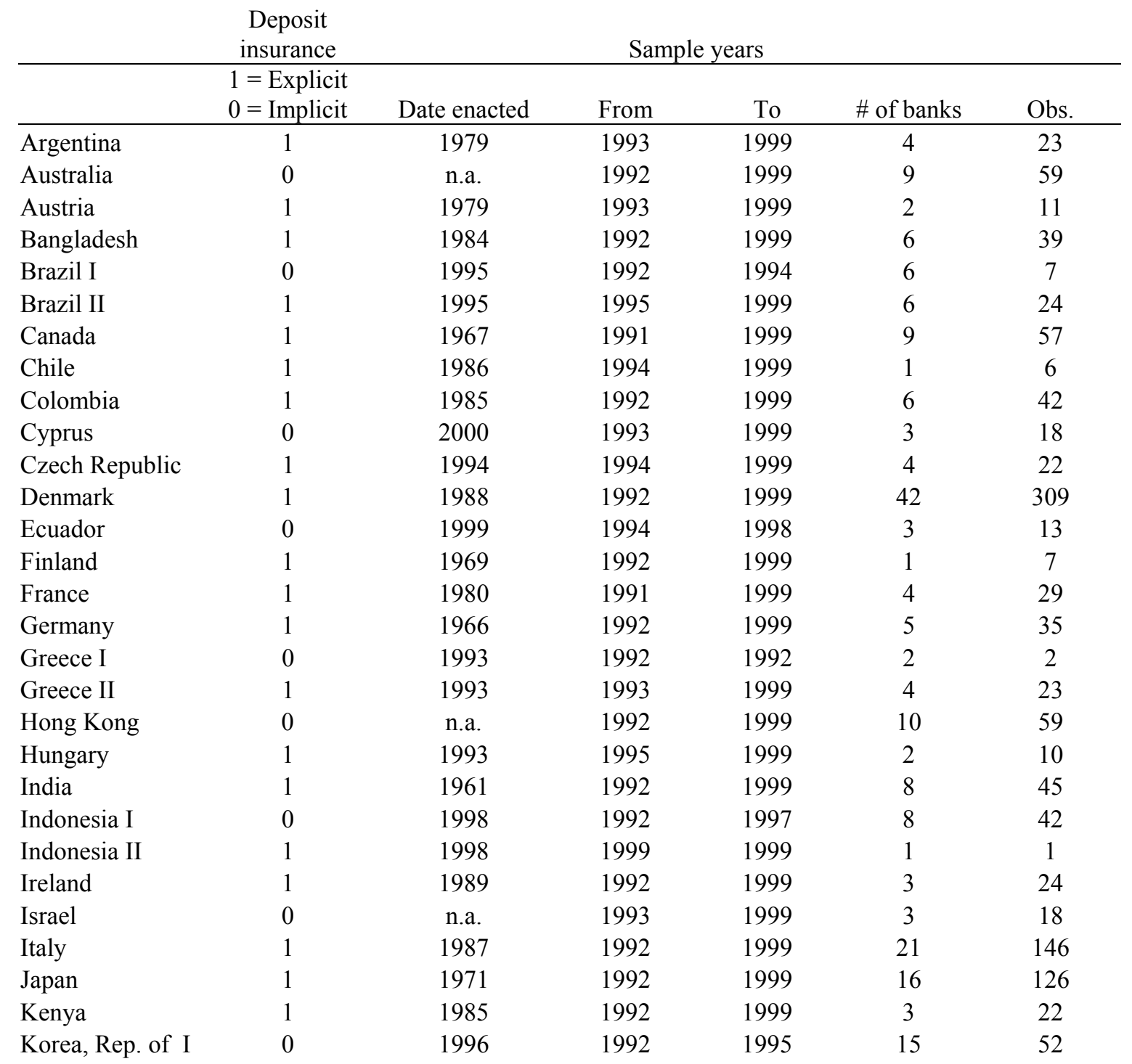




\begin{tabular}{|c|c|c|c|c|c|c|}
\hline Korea, Rep. of II & 1 & 1996 & 1996 & 1999 & 16 & 47 \\
\hline Luxembourg & 1 & 1989 & 1992 & 1999 & 2 & 16 \\
\hline Malaysia I & 0 & 1998 & 1993 & 1997 & 9 & 36 \\
\hline Malaysia II & 1 & 1998 & 1998 & 1999 & 9 & 16 \\
\hline Morocco I & 0 & 1996 & 1993 & 1995 & 5 & 15 \\
\hline Morocco II & 1 & 1996 & 1996 & 1999 & 5 & 19 \\
\hline Netherlands & 1 & 1979 & 1992 & 1999 & 2 & 12 \\
\hline Norway & 1 & 1961 & 1992 & 1999 & 11 & 66 \\
\hline Pakistan & 0 & n.a. & 1992 & 1999 & 7 & 41 \\
\hline Peru & 1 & 1992 & 1993 & 1999 & 4 & 21 \\
\hline Philippines & 1 & 1963 & 1992 & 1999 & 10 & 64 \\
\hline Poland & 1 & 1995 & 1995 & 1999 & 6 & 26 \\
\hline Portugal & 1 & 1992 & 1992 & 1999 & 4 & 28 \\
\hline Russia & 0 & n.a. & 1995 & 1998 & 1 & 4 \\
\hline Singapore & 0 & n.a. & 1992 & 1999 & 6 & 45 \\
\hline South Africa & 0 & n.a. & 1992 & 1999 & 4 & 29 \\
\hline Spain & 1 & 1977 & 1992 & 1999 & 12 & 96 \\
\hline Sri Lanka & 1 & 1987 & 1992 & 1999 & 3 & 16 \\
\hline Sweden I & 0 & 1996 & 1992 & 1995 & 3 & 7 \\
\hline Sweden II & 1 & 1996 & 1996 & 1999 & 3 & 12 \\
\hline Switzerland & 1 & 1984 & 1992 & 1999 & 5 & 38 \\
\hline Taiwan & 1 & 1985 & 1992 & 1999 & 15 & 76 \\
\hline Thailand I & 0 & 1997 & 1991 & 1996 & 7 & 35 \\
\hline Thailand II & 1 & 1997 & 1997 & 1999 & 5 & 13 \\
\hline United Kingdom & 1 & 1982 & 1992 & 1999 & 8 & 60 \\
\hline United States & 1 & 1934 & 1992 & 1999 & 19 & 133 \\
\hline Zimbabwe & 0 & n.a. & 1993 & 1999 & 2 & 13 \\
\hline Total & & & & & 390 & 2255 \\
\hline
\end{tabular}

Notes: Countries that introduced deposit insurance during the sample period are reported twice - before and after the enactment of deposit insurance. n.a. indicates "not applicable". In Cyprus, explicit deposit insurance was introduced in March 2000, after the sample period. Although Thailand and Malaysia do not have an explicit deposit insurance fund, their governments introduced blanket guarantees in 1997 and 1998, respectively. In effect, these guarantees imply explicit deposit insurance. 


\section{Table II}

Mean Leverage, Volatility, and Fair Insurance Premiums Found in Different Subsamples

The aggregate sample consists of 2,255 observations and covers risk-shifting behavior from 1991 to 1999 . $\mathrm{B}$ is the face value of a bank's debt, including deposits. V is the market value of a bank's assets. IPP is the banks' fair deposit insurance premium. $\sigma_{\mathrm{V}}$ is the standard deviation of the banks' asset returns.

\begin{tabular}{|c|c|c|c|c|}
\hline & (1) & (2) & (3) & (4) \\
\hline & \multicolumn{2}{|c|}{ All 56 Countries } & \multicolumn{2}{|c|}{$\begin{array}{l}\text { Countries with a change in deposit } \\
\text { insurance status }\end{array}$} \\
\hline & $\begin{array}{c}\text { Years without } \\
\text { Explicit Insurance }\end{array}$ & $\begin{array}{l}\text { Years with Explicit } \\
\text { Insurance }\end{array}$ & $\begin{array}{c}\text { Years without } \\
\text { Explicit Insurance }\end{array}$ & $\begin{array}{l}\text { Years with Explicit } \\
\text { Insurance }\end{array}$ \\
\hline \multicolumn{5}{|c|}{ Merton model with minimal forbearance } \\
\hline $\mathrm{B} / \mathrm{V}$ & 0.879 & $0.891 * *$ & 0.884 & $0.914 * *$ \\
\hline$\sigma_{\mathrm{V}}$ & 0.049 & $0.039 * *$ & 0.050 & 0.055 \\
\hline IPP (\%) & 0.180 & 0.127 & 0.211 & $0.617 * *$ \\
\hline \multicolumn{5}{|c|}{ Ronn and Verma (1986) with forbearance } \\
\hline $\mathrm{B} / \mathrm{V}$ & 0.903 & $0.915 * *$ & 0.909 & $0.939 * *$ \\
\hline$\sigma_{\mathrm{V}}$ & 0.050 & $0.040 * *$ & 0.052 & 0.056 \\
\hline IPP (\%) & 0.357 & 0.313 & 0.426 & $1.245^{* *}$ \\
\hline \multicolumn{5}{|c|}{ Hovakimian and Kane (2000) with forbearance } \\
\hline $\mathrm{B} / \mathrm{V}$ & 0.879 & $0.891 * *$ & 0.885 & $0.918 * *$ \\
\hline$\sigma_{\mathrm{V}}$ & 0.050 & $0.040 * *$ & 0.051 & 0.059 \\
\hline IPP (\%) & 0.264 & 0.211 & 0.325 & $1.029 * *$ \\
\hline Sample Size & 495 & 1760 & 196 & 155 \\
\hline
\end{tabular}

*** Significantly different from the value in the "Years Without Explicit Insurance" column at 5 and 1 percent, respectively. 
Table III

Mean IPP Value for Each Sample Country

(Expressed as a \% of Deposits)

\begin{tabular}{|c|c|c|c|}
\hline Country & $\begin{array}{l}\text { Merton model with } \\
\text { minimal forbearance }\end{array}$ & $\begin{array}{c}\text { Ronn and Verma (1986) } \\
\text { with forbearance }\end{array}$ & $\begin{array}{l}\text { Hovakimian and Kane } \\
\text { (2000) with forbearance }\end{array}$ \\
\hline Argentina & 0.361 & 0.579 & 0.379 \\
\hline Australia & 0.000 & 0.005 & 0.000 \\
\hline Austria & 0.000 & 0.374 & 0.001 \\
\hline Bangladesh & 0.067 & 0.769 & 0.165 \\
\hline Brazil & 0.923 & 1.701 & 1.333 \\
\hline Canada & 0.013 & 0.143 & 0.036 \\
\hline Chile & 0.003 & 0.018 & 0.003 \\
\hline Colombia & 0.039 & 0.107 & 0.056 \\
\hline Cyprus & 0.043 & 0.097 & 0.043 \\
\hline Czech Republic & 0.057 & 0.323 & 0.116 \\
\hline Denmark & 0.091 & 0.178 & 0.097 \\
\hline Ecuador & 0.062 & 0.176 & 0.070 \\
\hline Finland & 0.010 & 0.109 & 0.015 \\
\hline France & 0.004 & 0.105 & 0.006 \\
\hline Germany & 0.000 & 0.152 & 0.000 \\
\hline Greece & 0.183 & 0.408 & 0.187 \\
\hline Hong Kong & 0.441 & 0.614 & 0.461 \\
\hline Hungary & 0.078 & 0.422 & 0.099 \\
\hline India & 0.192 & 0.603 & 0.305 \\
\hline Indonesia & 0.466 & 0.798 & 0.600 \\
\hline Ireland & 0.002 & 0.018 & 0.002 \\
\hline Israel & 0.001 & 0.093 & 0.002 \\
\hline Italy & 0.016 & 0.135 & 0.033 \\
\hline Japan & 0.090 & 0.417 & 0.229 \\
\hline Kenya & 0.708 & 1.018 & 0.843 \\
\hline Korea, Rep. of & 0.280 & 0.853 & 0.526 \\
\hline Luxembourg & 0.000 & 0.066 & 0.000 \\
\hline Malaysia & 0.350 & 0.618 & 0.431 \\
\hline Morocco & 0.002 & 0.042 & 0.002 \\
\hline Netherlands & 0.003 & 0.030 & 0.003 \\
\hline Norway & 0.002 & 0.174 & 0.004 \\
\hline Pakistan & 0.078 & 0.403 & 0.172 \\
\hline Peru & 0.350 & 0.670 & 0.436 \\
\hline Philippines & 0.408 & 0.623 & 0.442 \\
\hline Poland & 0.155 & 0.276 & 0.163 \\
\hline Portugal & 0.005 & 0.058 & 0.006 \\
\hline Russia & 1.928 & 2.943 & 2.205 \\
\hline Singapore & 0.013 & 0.040 & 0.015 \\
\hline South Africa & 0.054 & 0.211 & 0.059 \\
\hline Spain & 0.051 & 0.073 & 0.052 \\
\hline Sri Lanka & 0.112 & 0.358 & 0.130 \\
\hline Sweden & 0.021 & 0.214 & 0.111 \\
\hline Switzerland & 0.002 & 0.006 & 0.002 \\
\hline
\end{tabular}




\begin{tabular}{llll} 
Taiwan & 0.020 & 0.059 & 0.021 \\
Thailand & 0.780 & 1.189 & 0.956 \\
United Kingdom & 0.011 & 0.092 & 0.012 \\
United States & 0.002 & 0.009 & 0.002 \\
Zimbabwe & 0.536 & 1.157 & 0.803 \\
\hline Unweighted Sample Mean & 0.139 & 0.323 & 0.222 \\
\hline
\end{tabular}




\section{Table IV}

\section{Evidence of Risk-Shifting Control, Using the Merton model with minimal forbearance}

Fixed-effects regressions relating a bank's leverage, $\mathrm{B} / \mathrm{V}$, and fair deposit insurance premium, IPP, to the volatility of its return on assets, $\sigma_{\mathrm{V}}$, and particular deposit-insurance design features. B is the face value of a bank's debt, including deposits. V is the market value of a bank's assets. Regression input comes from the Merton single-period model of deposit with minimal forbearance. The sample consists of 2,255 observations covering risk-shifting behavior from 1991 to 1999 . Estimates that differ significantly from zero at $5 \%$, and $1 \%$ levels are marked *, and **, respectively.

Panel A. Unconstrained fair deposit insurance premium regressions.

\begin{tabular}{|c|c|c|c|c|c|c|c|c|}
\hline & \multicolumn{2}{|c|}{ (1) } & \multicolumn{2}{|c|}{ (2) } & \multicolumn{2}{|c|}{ (3) } & \multicolumn{2}{|c|}{ (4) } \\
\hline & Coeff. & t-ratio & Coeff. & t-ratio & Coeff. & t-ratio & Coeff. & t-ratio \\
\hline Leverage & $9.600 * *$ & 37.0 & $9.646 * *$ & 37.2 & $9.527 * *$ & 36.6 & $9.292 * *$ & 32.2 \\
\hline$\sigma_{\mathrm{V}}$ & $21.025 * *$ & 57.2 & $22.580 * *$ & 37.4 & $22.590 * *$ & 37.6 & $23.238 * *$ & 39.6 \\
\hline EI Dummy $\times \sigma_{V}$ & & & $-1.985^{*}$ & -3.2 & $-1.647 *$ & -2.7 & $2.658 * *$ & 3.6 \\
\hline Risk-Sensitive Premium Dummy $\times \sigma_{\mathrm{V}}$ & & & & & $-3.266 * *$ & -3.5 & $-3.622 * *$ & -3.9 \\
\hline Coinsurance Dummy $\times \sigma_{\mathrm{V}}$ & & & & & & & $-3.510^{*}$ & -2.4 \\
\hline Coverage Limits Dummy $\times \sigma_{\mathrm{V}}$ & & & & & & & $-6.704 * *$ & -8.6 \\
\hline R-squared & 0.727 & & 0.728 & & 0.730 & & 0.759 & \\
\hline Sample Size & 2255 & & 2255 & & 2255 & & 1981 & \\
\hline
\end{tabular}

Panel B. Leverage regressions.

\begin{tabular}{|c|c|c|c|c|c|c|c|c|}
\hline & \multicolumn{2}{|c|}{ (1) } & \multicolumn{2}{|c|}{ (2) } & \multicolumn{2}{|c|}{ (3) } & \multicolumn{2}{|c|}{ (4) } \\
\hline & Coeff. & t-ratio & Coeff. & t-ratio & Coeff. & t-ratio & Coeff. & t-ratio \\
\hline$\sigma_{\mathrm{V}}$ & $-0.723 * *$ & -25.9 & $-0.822 * *$ & -16.5 & $-0.806 * *$ & -16.3 & $-0.728 * *$ & -15.8 \\
\hline EI Dummy $\times \sigma_{\mathrm{V}}$ & & & $0.129 *$ & 2.4 & $0.177 * *$ & 3.3 & $0.477 * *$ & 7.7 \\
\hline Risk-Sensitive Premium Dummy $\times \sigma_{\mathrm{V}}$ & & & & & $-0.478 * *$ & -5.8 & $-0.597 * *$ & -7.6 \\
\hline Coinsurance Dummy $\times \sigma_{\mathrm{V}}$ & & & & & & & $-0.692 * *$ & -5.7 \\
\hline Coverage Limits Dummy $\times \sigma_{\mathrm{V}}$ & & & & & & & $-0.303 * *$ & -4.6 \\
\hline R-squared & 0.774 & & 0.775 & & 0.779 & & 0.792 & \\
\hline Sample Size & 2255 & & 2255 & & 2255 & & 1981 & \\
\hline
\end{tabular}


Panel C. Constrained IPP regressions.

\begin{tabular}{|c|c|c|c|c|c|c|c|c|}
\hline & \multicolumn{2}{|c|}{ (1) } & \multicolumn{2}{|c|}{ (2) } & \multicolumn{2}{|c|}{ (3) } & \multicolumn{2}{|c|}{ (4) } \\
\hline & Coeff. & t-ratio & Coeff. & t-ratio & Coeff. & t-ratio & Coeff. & t-ratio \\
\hline$\sigma_{\mathrm{V}}$ & $14.086 * *$ & 34.0 & $14.651 * *$ & 19.8 & $14.908 * *$ & 20.3 & $16.470 * *$ & 23.7 \\
\hline EI Dummy $\times \sigma_{V}$ & & & -0.737 & -0.9 & 0.036 & 0.0 & $7.086 * *$ & 7.6 \\
\hline Risk-Sensitive Premium Dummy $\times \sigma_{V}$ & & & & & $-7.820 * *$ & -6.4 & $-9.171 * *$ & -7.8 \\
\hline Coinsurance Dummy $\times \sigma_{V}$ & & & & & & & $-9.940 * *$ & -5.5 \\
\hline Coverage Limits Dummy $\times \sigma_{\mathrm{V}}$ & & & & & & & $-9.515 * *$ & -9.7 \\
\hline R-squared & 0.530 & & 0.531 & & 0.541 & & 0.611 & \\
\hline Sample Size & 2255 & & 2255 & & 2255 & & 1981 & \\
\hline
\end{tabular}


Table V

\section{Evidence of Risk-Shifting Control, Using the Adapted Ronn and Verma model with substantial forbearance}

Fixed-effects regressions relating a bank's leverage, B/V, and fair deposit insurance premiums, IPP, to the volatility of its return on assets, $\sigma_{\mathrm{V}}$, and particular deposit-insurance design features. $\mathrm{B}$ is the face value of a bank's debt, including deposits. $\mathrm{V}$ is the market value of a bank's assets. Regression input comes from the adapted RV model of deposit insurance with forbearance. The sample consists of 2,255 observations covering risk-shifting behavior from 1991 to 1999. Estimates that differ significantly from zero at $5 \%$ and $1 \%$ levels are marked *, and **, respectively.

Panel A. Unconstrained fair deposit insurance premium regressions.

\begin{tabular}{|c|c|c|c|c|c|c|c|c|}
\hline & \multicolumn{2}{|c|}{ (1) } & \multicolumn{2}{|c|}{ (2) } & \multicolumn{2}{|c|}{ (3) } & \multicolumn{2}{|c|}{ (4) } \\
\hline & Coeff. & t-ratio & Coeff. & t-ratio & Coeff. & t-ratio & Coeff. & t-ratio \\
\hline Leverage & $12.640 * *$ & 44.4 & $12.647 * *$ & 44.4 & $12.543 * *$ & 43.7 & $12.733 * *$ & 39.8 \\
\hline$\sigma_{\mathrm{V}}$ & $24.845 * *$ & 59.8 & $25.097 * *$ & 36.7 & $25.107 * *$ & 36.8 & $25.987 * *$ & 38.8 \\
\hline EI Dummy $\times \sigma_{V}$ & & & -0.321 & -0.5 & -0.016 & 0.0 & $3.819 * *$ & 4.5 \\
\hline Risk-Sensitive Premium Dummy $\times \sigma_{\mathrm{V}}$ & & & & & $-2.953 *$ & -2.8 & $-2.705^{*}$ & -2.5 \\
\hline Coinsurance Dummy $\times \sigma_{\mathrm{V}}$ & & & & & & & -2.022 & -1.2 \\
\hline Coverage Limits Dummy $\times \sigma_{\mathrm{V}}$ & & & & & & & $-6.519 * *$ & -7.4 \\
\hline R-squared & 0.769 & & 0.769 & & 0.770 & & 0.792 & \\
\hline Sample Size & 2255 & & 2255 & & 2255 & & 1981 & \\
\hline
\end{tabular}

Panel B. Leverage regressions.

\begin{tabular}{|c|c|c|c|c|c|c|c|c|}
\hline & \multicolumn{2}{|c|}{ (1) } & \multicolumn{2}{|c|}{ (2) } & \multicolumn{2}{|c|}{ (3) } & \multicolumn{2}{|c|}{ (4) } \\
\hline & Coeff. & t-ratio & Coeff. & t-ratio & Coeff. & t-ratio & Coeff. & t-ratio \\
\hline$\sigma_{\mathrm{V}}$ & $-0.743 * *$ & -25.8 & $-0.849 * *$ & -16.5 & $-0.833 * *$ & -16.3 & $-0.752 * *$ & -15.8 \\
\hline EI Dummy $\times \sigma_{\mathrm{V}}$ & & & $0.138^{*}$ & 2.5 & $0.186^{* *}$ & 3.3 & $0.492 * *$ & 7.7 \\
\hline Risk-Sensitive Premium Dummy $\times \sigma_{\mathrm{V}}$ & & & & & $-0.492 * *$ & -5.8 & $-0.613 * *$ & -7.6 \\
\hline Coinsurance Dummy $\times \sigma_{\mathrm{V}}$ & & & & & & & $-0.705 * *$ & -5.7 \\
\hline Coverage Limits Dummy $\times \sigma_{\mathrm{V}}$ & & & & & & & $-0.310 * *$ & -4.6 \\
\hline R-squared & 0.774 & & 0.775 & & 0.779 & & 0.791 & \\
\hline Sample Size & 2255 & & 2255 & & 2255 & & 1981 & \\
\hline
\end{tabular}


Panel C. Constrained IPP regressions.

\begin{tabular}{|c|c|c|c|c|c|c|c|c|}
\hline & \multicolumn{2}{|c|}{$(1)$} & \multicolumn{2}{|c|}{ (2) } & \multicolumn{2}{|c|}{ (3) } & \multicolumn{2}{|c|}{ (4) } \\
\hline & Coeff. & t-ratio & Coeff. & t-ratio & Coeff. & t-ratio & Coeff. & t-ratio \\
\hline$\sigma_{\mathrm{V}}$ & $15.449 * *$ & 30.3 & $14.360 * *$ & 15.8 & $14.664 * *$ & 16.2 & $16.408 * *$ & 18.8 \\
\hline EI Dummy $\times \sigma_{\mathrm{V}}$ & & & 1.420 & 1.4 & $2.321 *$ & 2.4 & $10.085 * *$ & 8.7 \\
\hline Risk-Sensitive Premium Dummy $\times \sigma_{\mathrm{V}}$ & & & & & $-9.130 * *$ & -6.1 & $-10.510 * *$ & -7.1 \\
\hline Coinsurance Dummy $\times \sigma_{\mathrm{V}}$ & & & & & & & $-11.002 * *$ & -4.8 \\
\hline Coverage Limits Dummy $\times \sigma_{\mathrm{V}}$ & & & & & & & $-10.469 * *$ & -8.5 \\
\hline R-squared & 0.530 & & 0.530 & & 0.539 & & 0.596 & \\
\hline Sample Size & 2255 & & 2255 & & 2255 & & 1981 & \\
\hline
\end{tabular}




\section{Table VI}

\section{Evidence of Risk-Shifting Control, generated from the minimal-forbearance Merton model}

\section{for countries changing deposit insurance status during 1991-99}

Fixed-effects regressions relating a bank's leverage, $\mathrm{B} / \mathrm{V}$, and fair deposit insurance premiums, IPP, to the volatility of its return on assets, $\sigma_{\mathrm{V}}$, and specified deposit-insurance design features: $\mathrm{B}$ is the face value of a bank's debt, including deposits. V is the market value of a bank's assets. Regression input comes from Merton's single-period model of deposit insurance with minimal forbearance. The sample consists of 351 observations in countries that installed explicit insurance between 1991 and 1999. Estimates that differ significantly from zero at $5 \%$ and $1 \%$ levels are marked $*$, and $* *$, respectively.

Panel A. Unconstrained fair deposit insurance premium regressions.

\begin{tabular}{lcccc} 
& Coeff. & t-ratio & Coeff. & t-ratio \\
\hline Leverage & $13.703^{* *}$ & 19.3 & $12.297^{* *}$ & 16.2 \\
$\sigma_{\mathrm{V}}$ & $32.592^{* *}$ & 24.0 & $32.069^{* *}$ & 24.1 \\
EI Dummy $\times \sigma_{\mathrm{V}}$ & $-4.856^{* *}$ & -3.9 & -1.549 & -1.1 \\
Risk-Sensitive Premium Dummy $\times \sigma_{\mathrm{V}}$ & & & 8.866 & 0.8 \\
Coverage Limits Dummy $\times \sigma_{\mathrm{V}}$ & & & $-7.748^{* *}$ & -4.5 \\
\hline R-squared & 0.844 & & 0.854 & \\
Sample Size & 351 & & 351 & \\
\hline
\end{tabular}

Panel B. Leverage regressions.

\begin{tabular}{lcccc} 
& Coeff. & t-ratio & Coeff. & t-ratio \\
\hline$\sigma_{\mathrm{V}}$ & $-0.776^{* *}$ & -7.5 & $-0.712^{* *}$ & -7.6 \\
EI Dummy $\times \sigma_{\mathrm{V}}$ & $0.452^{* *}$ & 4.6 & $0.798^{* *}$ & 8.0 \\
Risk-Sensitive Premium Dummy $\times \sigma_{\mathrm{V}}$ & & & -0.547 & -0.6 \\
Coverage Limits Dummy $\times \sigma_{\mathrm{V}}$ & & & $-0.964^{* *}$ & -7.9 \\
\hline R-squared & 0.624 & & 0.692 & \\
Sample Size & 351 & & 351 & \\
\hline
\end{tabular}

Panel C. Constrained IPP regressions.

\begin{tabular}{lcccc} 
& Coeff. & t-ratio & Coeff. & t-ratio \\
\hline$\sigma_{\mathrm{V}}$ & $21.961^{* *}$ & 11.7 & $23.309^{* *}$ & 13.9 \\
EI Dummy $\times \sigma_{\mathrm{V}}$ & 1.341 & 0.7 & $8.264^{* *}$ & 4.6 \\
Risk-Sensitive Premium Dummy $\times \sigma_{\mathrm{V}}$ & & & -2.143 & 0.1 \\
Coverage Limits Dummy $\times \sigma_{\mathrm{V}}$ & & & $-19.605^{* *}$ & -9.0 \\
\hline R-squared & 0.643 & & 0.722 & \\
Sample Size & 351 & & 351 & \\
\hline
\end{tabular}




\section{Table VII}

\section{Differences in Risk-Shifting Control Across Environments Marked by Differences in}

\section{Political Freedom, using Merton Model with Minimal Forbearance}

Fixed-effects regressions relating a bank's leverage, B/V, and fair deposit insurance premium, IPP, to the volatility of return on assets, $\sigma_{\mathrm{V}}$. B is the face value of a bank's debt, including deposits. $\mathrm{V}$ is the market value of a bank's assets. Regression input come from Merton's single-period model of deposit insurance with minimal forbearance. The sample consists of 2,192 observations covering risk-shifting behavior from 1991 to 1999 . Estimates that differ significantly from zero at $5 \%$ and $1 \%$ levels are marked *, and **, respectively. In each panel, the last row reports the p-value of the F-test that the coefficients in the subsample regressions are the same.

Panel A. Unconstrained fair deposit insurance premium regressions.

\begin{tabular}{lcccccc} 
& \multicolumn{2}{c}{ Free } & \multicolumn{2}{c}{ Partly Free } & \multicolumn{2}{c}{ Not Free } \\
& Coeff. & t-ratio & Coeff. & t-ratio & Coeff. & t-ratio \\
\hline Leverage & $7.645^{* *}$ & 26.3 & $7.762 * *$ & 16.3 & $17.797 * *$ & 6.1 \\
$\sigma_{\mathrm{V}}$ & $11.969 * *$ & 11.5 & $16.329 * *$ & 13.6 & $31.079^{* *}$ & 3.5 \\
EI Dummy $\times \sigma_{\mathrm{V}}$ & $4.805^{* *}$ & 4.8 & $3.723 * *$ & 3.5 & $-3.649 * *$ & -0.4 \\
\hline R-squared & 0.812 & \multicolumn{7}{c}{0.811} & 0.731 & 51 \\
Sample Size & 1639 & 502 & & & \\
\hline F-test (p-value) & 0.00 &
\end{tabular}

Panel B. Leverage regressions.

\begin{tabular}{lcccccc} 
& \multicolumn{2}{c}{ Free } & \multicolumn{2}{c}{ Partly Free } & \multicolumn{2}{c}{ Not Free } \\
& Coeff. & t-ratio & Coeff. & t-ratio & Coeff. & t-ratio \\
\hline$\sigma_{\mathrm{V}}$ & $-1.258^{* *}$ & -13.9 & $-1.317^{* *}$ & -12.1 & $-1.847^{* *}$ & -4.7 \\
EI Dummy $\times \sigma_{\mathrm{V}}$ & $0.417^{* *}$ & 4.5 & $0.640^{* *}$ & 5.9 & $1.650^{* *}$ & 3.8 \\
\hline R-squared & 0.850 & & 0.759 & & 0.677 & \\
Sample Size & 1639 & & 502 & & 51 & \\
\hline F-test $(\mathrm{p}$-value) & 0.00 & \multicolumn{5}{c}{}
\end{tabular}

Panel C. Constrained IPP regressions.

\begin{tabular}{lcccccc} 
& \multicolumn{2}{c}{ Free } & \multicolumn{2}{c}{ Partly Free } & \multicolumn{2}{c}{ Not Free } \\
& Coeff. & t-ratio & Coeff. & t-ratio & Coeff. & t-ratio \\
\hline$\sigma_{\mathrm{V}}$ & $2.355^{*}$ & 2.0 & $6.104^{* *}$ & 4.6 & -1.806 & -0.2 \\
EI Dummy $\times \sigma_{\mathrm{V}}$ & $7.992^{* *}$ & 6.5 & $8.690^{* *}$ & 6.6 & $25.710^{*}$ & 2.3 \\
\hline R-squared & 0.717 & & 0.681 & & 0.458 & \\
Sample Size & 1639 & & 502 & & 51 & \\
\hline F-test $($ p-value) & 0.00 & & & & \\
\hline
\end{tabular}




\section{Table VIII}

\section{Evidence of Risk-Shifting Control Across Environments Marked by Differences in}

Economic Freedom, using Merton's Minimal-Forbearance Model

Fixed-effects regressions relating a bank's leverage, $\mathrm{B} / \mathrm{V}$, and fair deposit insurance premium, IPP, to the volatility of its return on assets, $\sigma_{\mathrm{V}} . \mathrm{B}$ is the face value of a bank's debt, including deposits. $\mathrm{V}$ is the market value of a bank's assets. Regression input comes from Merton's single-period model of deposit insurance with minimal forbearance. The sample consists of 1,533 observations covering risk-shifting behavior from 1995 to 1999 . Estimates that differ significantly from zero at 5\% and 1\% levels are marked *, and ${ }^{* *}$, respectively. In each panel, the last row reports the p-value of the F-test that the coefficients in the subsample regressions are the same.

Panel A. Unconstrained fair deposit insurance premium regressions.

\begin{tabular}{lcccc} 
& \multicolumn{2}{c}{ Free } & \multicolumn{2}{c}{ Not Free } \\
& Coeff. & t-ratio & Coeff. & t-ratio \\
\hline Leverage & $6.718^{* *}$ & 15.2 & $9.316^{* *}$ & 19.0 \\
$\sigma_{\mathrm{V}}$ & $20.986^{* *}$ & 29.8 & $14.768^{* *}$ & 10.2 \\
EI Dummy $\times \sigma_{\mathrm{V}}$ & $-6.013^{* *}$ & -6.0 & $4.791^{* *}$ & 3.6 \\
\hline R-squared & 0.765 & & 0.754 & \\
Sample Size & 820 & & 713 & \\
F-test $(p-$-value $)$ & 0.00 & & & \\
\hline
\end{tabular}

Panel B. Leverage regressions.

\begin{tabular}{|c|c|c|c|c|}
\hline & \multicolumn{2}{|c|}{ Free } & \multicolumn{2}{|c|}{ Not Free } \\
\hline & Coeff. & t-ratio & Coeff. & t-ratio \\
\hline$\overline{\sigma_{\mathrm{V}}}$ & $-0.229 * *$ & -3.6 & $-1.354 * *$ & -12.0 \\
\hline EI Dummy $\times \sigma_{\mathrm{V}}$ & $-0.838 * *$ & -9.8 & $0.760 * *$ & 6.8 \\
\hline R-squared & 0.899 & & 0.783 & \\
\hline Sample Size & 820 & & 713 & \\
\hline F-test (p-value) & 0.00 & & & \\
\hline
\end{tabular}

Panel C. Constrained IPP regressions.

\begin{tabular}{lcccc} 
& \multicolumn{2}{c}{ Free } & & Not Free \\
& Coeff. & t-ratio & Coeff. & t-ratio \\
\hline$\sigma_{\mathrm{V}}$ & $19.451^{* *}$ & 23.7 & 2.151 & 1.3 \\
EI Dummy $\times \sigma_{\mathrm{V}}$ & $-11.646^{* *}$ & -10.6 & $11.869^{* *}$ & 7.2 \\
\hline R-squared & 0.675 & & 0.589 & \\
Sample Size & 820 & & 713 & \\
F-test (p-value) & 0.00 & & & \\
\hline
\end{tabular}




\section{Table IX}

\section{Evidence of Risk-Shifting Control Across Environments that Differ in Corruption}

Fixed-effects regressions relating a bank's leverage, $\mathrm{B} / \mathrm{V}$, and fair deposit insurance premium, IPP, to the volatility of its return on assets, $\sigma_{\mathrm{V}} . \mathrm{B}$ is the face value of a bank's debt, including deposits. $\mathrm{V}$ is the market value of a bank's assets. Regression input comes from Merton's single-period model of deposit insurance with minimal forbearance. The sample consists of 1,401 observations covering risk-shifting behavior from 1995 to 1999 . Estimates that differ significantly from zero at $5 \%$ and $1 \%$ levels are marked *, and **, respectively. In each panel, the last row reports the p-value of the F-test of the hypothesis that the coefficients are the same across each pair of subsamples.

Panel A. Unconstrained fair deposit insurance premium regressions.

\begin{tabular}{lcccc} 
& \multicolumn{2}{c}{ Less Corrupt } & \multicolumn{2}{c}{ More Corrupt } \\
& Coeff. & t-ratio & Coeff. & t-ratio \\
\hline Leverage & $6.089^{* *}$ & 19.4 & $11.140^{* *}$ & 17.4 \\
$\sigma_{\mathrm{V}}$ & $19.574^{* *}$ & 34.7 & $17.914^{* *}$ & 6.2 \\
EI Dummy $\times \sigma_{\mathrm{V}}$ & $-6.889^{* *}$ & -10.6 & $5.965^{*}$ & 2.3 \\
\hline R-squared & 0.795 & & 0.807 & \\
Sample Size & 915 & & 486 & \\
F-test $(p$-value) & 0.00 & & & \\
\hline
\end{tabular}

Panel B. Leverage regressions.

\begin{tabular}{lcccc} 
& \multicolumn{2}{c}{ Less Corrupt } & \multicolumn{2}{c}{ More Corrupt } \\
& Coeff. & t-ratio & Coeff. & t-ratio \\
\hline$\sigma_{\mathrm{V}}$ & $-0.479^{* *}$ & -7.3 & $-2.138^{* *}$ & -9.9 \\
EI Dummy $\times \sigma_{\mathrm{V}}$ & 0.061 & 0.8 & $1.468^{* *}$ & 7.0 \\
\hline R-squared & 0.870 & & 0.788 & \\
Sample Size & 915 & & 486 & \\
\hline F-test $($ p-value $)$ & 0.00 & & & \\
\hline
\end{tabular}

Panel C. Constrained IPP regressions.

\begin{tabular}{lcccc} 
& \multicolumn{2}{c}{ Less Corrupt } & \multicolumn{2}{c}{ More Corrupt } \\
& Coeff. & t-ratio & Coeff. & t-ratio \\
\hline$\sigma_{\mathrm{V}}$ & $16.656^{* *}$ & 24.7 & $-5.906^{*}$ & -1.7 \\
EI Dummy $\times \sigma_{\mathrm{V}}$ & $-6.517^{* *}$ & -8.1 & $22.319^{* *}$ & 6.6 \\
\hline R-squared & 0.682 & & 0.630 & \\
Sample Size & 915 & & 486 & \\
F-test (p-value) & 0.00 & & & \\
\hline
\end{tabular}


Table X

\section{Evidence of Risk-Shifting Control Incorporating Deposit-Insurance Design Features and Country Characteristics}

Fixed-effects regressions relating a bank's leverage, B/V, and fair deposit insurance premiums, IPP, to the volatility of its return on assets, $\sigma_{\mathrm{V}}$, and specified deposit-insurance design features: $\mathrm{B}$ is the face value of the market value of a bank's assets. Regression input comes from Merton's single-period model of deposit insurance with minimal forbearance. Higher values of political freedom index correspond to less freedom. Higher values of economic freedom index correspond to less freedom. Higher values of corruption index correspond to less corruption. The sample consists of observations in countries for which the included country indices exist. Estimates that differ significantly from zero at 5\% and 1\% levels are marked $*$, and **, respectively.

Panel A. Leverage regressions.

\begin{tabular}{|c|c|c|c|c|c|c|c|c|}
\hline & \multicolumn{2}{|l|}{ (1) } & \multicolumn{2}{|l|}{ (2) } & \multicolumn{2}{|c|}{ (3) } & \multicolumn{2}{|l|}{ (4) } \\
\hline & Coeff. & t-ratio & Coeff. & t-ratio & Coeff. & t-ratio & Coeff. & t-ratio \\
\hline$\sigma_{\mathrm{V}}$ & $-1.056^{* *}$ & -12.6 & -0.229 & -1.8 & $-0.852 * *$ & -6.9 & $-1.464 * *$ & -3.5 \\
\hline $\begin{array}{l}\text { EI } \times \sigma_{V} \\
\text { Risk-Sensitive Premium }\end{array}$ & $0.646^{* *}$ & 10.2 & $0.624 * *$ & 9.0 & $0.606^{* *}$ & 7.6 & $1.175^{* *}$ & 12.3 \\
\hline Dummy $\times \sigma_{V}$ & $-0.564 * *$ & -7.4 & $-0.507 * *$ & -5.6 & $-0.524 * *$ & -4.9 & $-0.417 * *$ & -4.1 \\
\hline Coinsurance Dummy $\times \sigma_{\mathrm{V}}$ & $-0.650 * *$ & -5.5 & $-0.556^{* *}$ & -4.7 & $-0.544 * *$ & -4.4 & $-0.521 * *$ & -4.4 \\
\hline Coverage Limits Dummy $\times \sigma_{\mathrm{V}}$ & $-0.252 * *$ & -3.9 & $-0.444 * *$ & -6.2 & $-0.657 * *$ & -8.4 & $-0.263^{*}$ & -2.5 \\
\hline $\begin{array}{l}\text { Political Freedom Index } \times \sigma_{\mathrm{V}} \\
\text { Economic Freedom Index } \times\end{array}$ & 0.064 & 1.4 & & & & & 0.164 & 1.8 \\
\hline$\sigma_{\mathrm{V}}$ & & & $-0.218^{* *}$ & -4.0 & & & -0.059 & -0.6 \\
\hline Corruption Index $\times \sigma_{\mathrm{V}}$ & & & & & $0.039^{*}$ & 2.4 & -0.030 & -1.2 \\
\hline R-squared & 0.800 & & 0.857 & & 0.847 & & 0.866 & \\
\hline Sample Size & 1918 & & 1332 & & 1193 & & 1092 & \\
\hline
\end{tabular}

Panel B. Fair deposit insurance premium regressions.

\begin{tabular}{|c|c|c|c|c|c|c|c|c|}
\hline & \multicolumn{2}{|c|}{ (1) } & \multicolumn{2}{|l|}{ (2) } & \multicolumn{2}{|l|}{ (3) } & \multicolumn{2}{|l|}{ (4) } \\
\hline & Coeff. & t-ratio & Coeff. & t-ratio & Coeff. & t-ratio & Coeff. & t-ratio \\
\hline$\sigma_{\mathrm{V}}$ & $9.913 * *$ & 7.6 & $14.963 * *$ & 8.8 & $24.141 * *$ & 16.6 & 1.084 & 0.2 \\
\hline $\begin{array}{l}\text { EI } \times \sigma_{V} \\
\text { Risk-Sensitive Premium }\end{array}$ & $8.525 * *$ & 8.7 & $10.860 * *$ & 11.5 & $6.582 * *$ & 7.0 & $16.712 * *$ & 16.6 \\
\hline Dummy $\times \sigma_{V}$ & $-8.565^{* *}$ & -7.3 & $-6.620 * *$ & -5.4 & $-4.093 * *$ & -3.3 & -1.512 & -1.4 \\
\hline Coinsurance Dummy $\times \sigma_{\mathrm{V}}$ & $-8.706^{* *}$ & -4.8 & $-6.198 * *$ & -3.9 & $-4.380 * *$ & -3.0 & $-3.182 * *$ & -2.6 \\
\hline Coverage Limits Dummy $\times \sigma_{\mathrm{V}}$ & $-8.604 * *$ & -8.7 & $-13.544 * *$ & -14.0 & $-15.759 * *$ & -17.2 & $-8.228 * *$ & -7.4 \\
\hline $\begin{array}{l}\text { Political Freedom Index } \times \sigma_{\mathrm{V}} \\
\text { Economic Freedom Index } \times\end{array}$ & $2.948 * *$ & 4.2 & & & & & $7.140 * *$ & 7.6 \\
\hline$\sigma_{\mathrm{V}}$ & & & -0.680 & -0.9 & & & -0.001 & 0.0 \\
\hline Corruption Index $\times \sigma_{\mathrm{V}}$ & & & & & $-1.180 * *$ & -6.2 & $-1.735 * *$ & -6.6 \\
\hline R-squared & 0.592 & & 0.702 & & 0.770 & & 0.808 & \\
\hline Sample Size & 1918 & & 1332 & & 1193 & & 1092 & \\
\hline
\end{tabular}




\section{Table XI}

\section{Evidence of Risk-Shifting Control, generated from the minimal-forbearance Merton model allowing for self-selection}

Fixed-effects regressions using Heckman's $(1976,1978)$ two-step method relating a bank's leverage, B/V, and fair deposit insurance premiums, IPP, to the volatility of its return on assets, $\sigma_{\mathrm{V}}$, and particular deposit-insurance design features. B is the face value of a bank's debt, including deposits. $\mathrm{V}$ is the market value of a bank's assets. The dependent variable of the first-stage Probit model is a dummy variable that indicates whether the design feature is selected or not. As design features we consider risk-sensitive premiums (column 1), coinsurance (column 2), and coverage limits (column 3). Regression input for the secondstage regression comes from the minimal-forbearance Merton model of deposit insurance. Estimates that differ significantly from zero at $5 \%$ and $1 \%$ levels are marked ${ }^{*}$, and ${ }^{* *}$, respectively.

Panel A. Leverage regressions

\begin{tabular}{|c|c|c|c|c|c|c|c|c|c|c|c|c|}
\hline & \multicolumn{4}{|c|}{ Risk-Sensitive Premia } & \multicolumn{4}{|c|}{ Coinsurance } & \multicolumn{4}{|c|}{ Coverage limit } \\
\hline & \multicolumn{2}{|c|}{ Self-selection } & \multicolumn{2}{|c|}{ OLS } & \multicolumn{2}{|c|}{ Self-selection } & \multicolumn{2}{|c|}{ OLS } & \multicolumn{2}{|c|}{ Self-selection } & \multicolumn{2}{|c|}{ OLS } \\
\hline & Coeff. & t-ratio & Coeff. & t-ratio & Coeff. & t-ratio & Coeff. & t-ratio & Coeff. & t-ratio & Coeff. & t-ratio \\
\hline$\sigma_{\mathrm{V}}$ & $-0.708 * *$ & -18.5 & $-0.710 * *$ & -18.4 & $-0.652 * *$ & -16.9 & $-0.670 * *$ & -17.4 & $-0.255^{* *}$ & -3.7 & $-0.245 * *$ & -3.6 \\
\hline Risk-Sensitive Premium Dummy $\times \sigma_{\mathrm{V}}$ & -0.192 & -1.3 & -0.205 & -1.5 & & & & & & & & \\
\hline Coinsurance Dummy $\times \sigma_{\mathrm{V}}$ & & & & & $-0.426 * *$ & -3.9 & $-0.421 * *$ & -3.9 & & & & \\
\hline Coverage Limits Dummy $\times \sigma_{V}$ & & & & & & & & & $-0.506^{* *}$ & -5.8 & $-0.539 * *$ & -6.2 \\
\hline Lambda & $-0.012 * *$ & -4.9 & & & $-0.007 * *$ & -3.4 & & & $0.539 *$ & -2.4 & & \\
\hline R-squared & & & 0.295 & & & & 0.300 & & & & 0.267 & \\
\hline Sample Size & 928 & & 928 & & 975 & & 975 & & 541 & & 541 & \\
\hline
\end{tabular}

Panel B. Constrained IPP regressions

\begin{tabular}{|c|c|c|c|c|c|c|c|c|c|c|c|c|}
\hline & \multicolumn{4}{|c|}{ Risk-Sensitive Premia } & \multicolumn{4}{|c|}{ Coinsurance } & \multicolumn{4}{|c|}{ Coverage limit } \\
\hline & \multicolumn{2}{|c|}{ Self-selection } & \multicolumn{2}{|c|}{ OLS } & \multicolumn{2}{|c|}{ Self-selection } & \multicolumn{2}{|c|}{ OLS } & \multicolumn{2}{|c|}{ Self-selection } & \multicolumn{2}{|c|}{ OLS } \\
\hline & Coeff. & t-ratio & Coeff. & t-ratio & Coeff. & t-ratio & Coeff. & t-ratio & Coeff. & t-ratio & Coeff. & t-ratio \\
\hline$\sigma_{\mathrm{V}}$ & $12.645^{* *}$ & 20.6 & $12.633 * *$ & 20.5 & $13.455^{* *}$ & 21.8 & $13.175^{* *}$ & 21.5 & $25.736^{* *}$ & 23.8 & $25.818^{* *}$ & 23.9 \\
\hline Risk-Sensitive Premium Dummy $\times \sigma_{V}$ & -2.074 & -0.8 & $-5.144 *$ & -2.4 & & & & & & & & \\
\hline Coinsurance Dummy $\times \sigma_{\mathrm{V}}$ & & & & & $-6.656 * *$ & -3.8 & $-6.581 * *$ & -3.8 & & & & \\
\hline Coverage Limits Dummy $\times \sigma_{\mathrm{V}}$ & & & & & & & & & $-18.495^{* *}$ & -13.3 & $-18.767 * *$ & -13.6 \\
\hline Lambda & $-0.094 *$ & -2.3 & & & $-0.105 * *$ & -3.2 & & & -0.044 & -1.3 & & \\
\hline R-squared & & & 0.316 & & & & 0.327 & & & & 0.533 & \\
\hline Sample Size & 928 & & 928 & & 975 & & 975 & & 541 & & 541 & \\
\hline
\end{tabular}




\section{Table XII}

\section{Switching Regression Model of Leverage Control with Sample Selection Based on Country Characteristics}

Fixed-effects regressions relating a bank's leverage, B/V, and fair deposit insurance premiums, IPP, to the volatility of its return on assets, $\sigma_{\mathrm{V}}$, and specified deposit-insurance design features: B is the face value of the market value of a bank's assets. Regression input comes from Merton's single-period model of deposit insurance with minimal forbearance. The sample consists of observations in countries for which the included country indices exist. Estimates that differ significantly from zero at $5 \%$ and $1 \%$ levels are marked $*$, and $* *$, respectively.

Panel A. Weak institutional environment selection equation.

\begin{tabular}{|c|c|c|c|c|c|c|c|c|}
\hline & \multicolumn{2}{|c|}{ (1) } & \multicolumn{2}{|c|}{ (2) } & \multicolumn{2}{|c|}{ (3) } & \multicolumn{2}{|c|}{ (4) } \\
\hline & Coeff. & t-ratio & Coeff. & t-ratio & Coeff. & t-ratio & Coeff. & t-ratio \\
\hline Intercept & $4.126^{* *}$ & 7.0 & $-1.671 * *$ & -8.7 & $-1.077 * *$ & -4.0 & $1.300 * *$ & 7.7 \\
\hline Political freedom Index & $0.695 * *$ & 4.3 & $1.088 * *$ & 7.3 & & & & \\
\hline Economic freedom Index & $-1.176^{* *}$ & -7.5 & & & $0.329 * *$ & 3.1 & & \\
\hline Corruption Index & $-0.365^{* *}$ & -9.5 & & & & & $-0.241 * *$ & -9.5 \\
\hline Observations & 1280 & & 1280 & & 1280 & & 1280 & \\
\hline
\end{tabular}

Panel B. Risk-shifting when the institutional environment is weak.

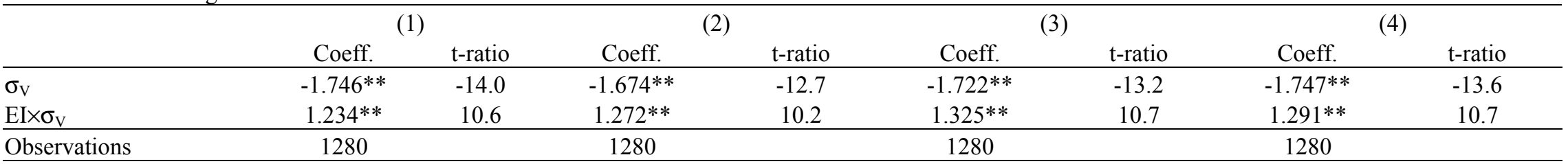

Panel C. Risk-shifting when the institutional environment is strong.

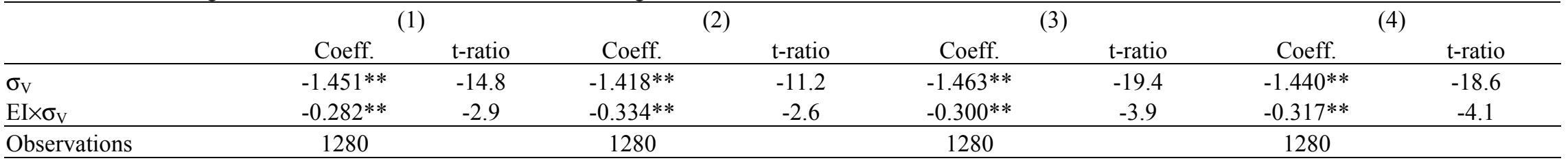




\section{Table XIII}

\section{Switching Regression Model of Fair Deposit Insurance Premiums with Sample Selection Based on Country Characteristics}

Fixed-effects regressions relating a bank's leverage, $\mathrm{B} / \mathrm{V}$, and fair deposit insurance premiums, IPP, to the volatility of its return on assets, $\sigma_{\mathrm{V}}$, and specified deposit-insurance design features: B is the face value of the market value of a bank's assets. Regression input comes from Merton's single-period model of deposit insurance with minimal forbearance. The sample consists of observations in countries for which the included country indices exist. Estimates that differ significantly from zero at $5 \%$ and $1 \%$ levels are marked $*$, and $* *$, respectively.

Panel A: Weak institutional environment selection equation

\begin{tabular}{|c|c|c|c|c|c|c|c|c|}
\hline & \multicolumn{2}{|c|}{ (1) } & \multicolumn{2}{|c|}{ (2) } & \multicolumn{2}{|c|}{ (3) } & \multicolumn{2}{|c|}{ (4) } \\
\hline & Coeff. & t-ratio & Coeff. & t-ratio & Coeff. & t-ratio & Coeff. & t-ratio \\
\hline Intercept & $1.418 * *$ & 3.5 & $-1.657 * *$ & -16.0 & $-2.371 * *$ & -13.4 & $1.680 * *$ & 15.8 \\
\hline Political freedom Index & $0.594 * *$ & 6.8 & $1.202 * *$ & 15.4 & & & & \\
\hline Economic freedom Index & $-0.247 *$ & -2.2 & & & $0.922 * *$ & 12.5 & & \\
\hline Corruption Index & $-0.281 * *$ & -10.6 & & & & & $-0.299 * *$ & -17.4 \\
\hline Observations & 1280 & & 1280 & & 1280 & & 1280 & \\
\hline
\end{tabular}

Panel B: Risk-shifting when the institutional environment is weak

\begin{tabular}{|c|c|c|c|c|c|c|c|c|}
\hline & \multicolumn{2}{|c|}{ (1) } & \multicolumn{2}{|c|}{ (2) } & \multicolumn{2}{|c|}{ (3) } & \multicolumn{2}{|c|}{ (4) } \\
\hline & Coeff. & t-ratio & Coeff. & t-ratio & Coeff. & t-ratio & Coeff. & t-ratio \\
\hline$\sigma_{\mathrm{V}}$ & -0.673 & -0.7 & -0.655 & -0.6 & -0.655 & -0.6 & -0.676 & -0.7 \\
\hline$\underline{\mathrm{EI} \times \sigma_{\mathrm{V}}}$ & $10.322 * *$ & 11.0 & $10.324 * *$ & 10.9 & $10.320 * *$ & 10.9 & $10.320 * *$ & 11.0 \\
\hline Observations & 1280 & & 1280 & & 1280 & & 1280 & \\
\hline
\end{tabular}

Panel C: Risk-shifting when the institutional environment is strong

\begin{tabular}{|c|c|c|c|c|c|c|c|c|}
\hline & \multicolumn{2}{|c|}{ (1) } & \multicolumn{2}{|c|}{ (2) } & \multicolumn{2}{|c|}{ (3) } & \multicolumn{2}{|c|}{ (4) } \\
\hline & Coeff. & t-ratio & Coeff. & t-ratio & Coeff. & t-ratio & Coeff. & t-ratio \\
\hline$\overline{\sigma_{V}}$ & $0.056^{*}$ & 2.1 & 0.049 & 1.6 & 0.050 & 1.9 & $0.053 *$ & 2.1 \\
\hline$\underline{\mathrm{EI} \times \sigma_{\mathrm{V}}}$ & 0.032 & 1.2 & 0.041 & 1.3 & 0.040 & 1.5 & 0.034 & 1.4 \\
\hline Observations & 1280 & & 1280 & & 1280 & & 1280 & \\
\hline
\end{tabular}




\section{Table XIV}

\section{Evidence of Risk-Shifting Control Across Regions}

Fixed-effects regressions relating a bank's leverage, $\mathrm{B} / \mathrm{V}$, and fair deposit insurance premiums, IPP, to the volatility of its return on assets, $\sigma_{\mathrm{V}}$, and specified deposit-insurance design features: B is the face value of the market value of a bank's assets. Regression input comes from Merton's single-period model of deposit insurance with minimal forbearance. Higher values of political freedom index correspond to less freedom. Higher values of economic freedom index correspond to less freedom. Higher values of corruption index correspond to less corruption. The sample consists of observations in countries for which the included country indices exist. Estimates that differ significantly from zero at $5 \%$ and $1 \%$ levels are marked *, and **, respectively.

Panel A. Unconstrained fair deposit insurance premium regressions.

\begin{tabular}{|c|c|c|c|c|c|c|c|c|c|c|c|c|c|c|c|c|c|c|}
\hline & \multicolumn{2}{|c|}{ Western Europe } & \multicolumn{2}{|c|}{ Eastern Europe } & \multicolumn{2}{|c|}{ North America } & \multicolumn{2}{|c|}{ Latin America } & \multicolumn{2}{|c|}{ Middle East } & \multicolumn{2}{|c|}{ Africa } & \multicolumn{2}{|c|}{ South Asia } & \multicolumn{2}{|c|}{ East Asia } & \multicolumn{2}{|c|}{ Australia } \\
\hline & Coeff. & t-ratio & Coeff. & t-ratio & Coeff. & t-ratio & Coeff. & t-ratio & Coeff. & t-ratio & Coeff. & t-ratio & Coeff. & t-ratio & Coeff. & t-ratio & Coeff. & t-ratio \\
\hline Leverage & 6.916 & 18.5 & 3.721 & 8.1 & 0.452 & 3.8 & 10.434 & 11.4 & 0.027 & 1.0 & 17.622 & 7.0 & 4.094 & 5.8 & 9.280 & 20.0 & 0.005 & 3.6 \\
\hline$\sigma_{\mathrm{V}}$ & 10.952 & 9.9 & 23.348 & 21.3 & 1.216 & 4.4 & 34.462 & 23.4 & 0.533 & 9.0 & 21.782 & 3.7 & 14.218 & 13.4 & 21.436 & 21.9 & 0.021 & 4.3 \\
\hline $\mathrm{EI} \times \sigma_{\mathrm{V}}$ & 3.264 & 3.0 & -14.176 & -11.7 & & & -17.894 & -9.8 & -0.262 & -4.3 & 4.485 & 0.7 & & & 4.067 & 4.1 & & \\
\hline R-squared & 0.691 & & 0.970 & & 0.359 & & 0.861 & & 0.723 & & 0.717 & & 0.738 & & 0.797 & & 0.416 & \\
\hline Sample Size & 939 & & 62 & & 190 & & 177 & & 52 & & 64 & & 100 & & 612 & & 59 & \\
\hline
\end{tabular}

Panel B. Leverage regressions.

\begin{tabular}{|c|c|c|c|c|c|c|c|c|c|c|c|c|c|c|c|c|c|c|}
\hline & \multicolumn{2}{|c|}{ Western Europe } & \multicolumn{2}{|c|}{ Eastern Europe } & \multicolumn{2}{|c|}{ North America } & \multicolumn{2}{|c|}{ Latin America } & \multicolumn{2}{|c|}{ Middle East } & \multicolumn{2}{|c|}{ Africa } & \multicolumn{2}{|c|}{ South Asia } & \multicolumn{2}{|c|}{ East Asia } & \multicolumn{2}{|c|}{ Australia } \\
\hline & Coeff. & t-ratio & Coeff. & t-ratio & Coeff. & t-ratio & Coeff. & t-ratio & Coeff. & t-ratio & Coeff. & t-ratio & Coeff. & t-ratio & Coeff. & t-ratio & Coeff. & t-ratio \\
\hline$\sigma_{\mathrm{V}}$ & $-1.045^{* *}$ & -10.7 & -0.418 & -1.2 & $-2.069 * *$ & -24.9 & $-0.481 * *$ & -3.7 & $-0.704 *$ & -2.1 & $-0.676^{*}$ & -2.2 & $-0.854 * *$ & -6.3 & $-0.843 * *$ & -9.9 & $-3.190 * *$ & -10 \\
\hline $\mathrm{EI} \times \sigma_{\mathrm{V}}$ & $0.231 *$ & 2.3 & $-0.780 *$ & -2.1 & & & $-0.533 * *$ & -3.3 & $-1.533 * *$ & -5.9 & 0.512 & 1.5 & & & 0.551 & 6.0 & & \\
\hline R-squared & 0.859 & & 0.843 & & 0.955 & & 0.759 & & 0.886 & & 0.699 & & 0.856 & & 0.666 & & 0.803 & \\
\hline Sample Size & 939 & & 62 & & 190 & & 177 & & 52 & & 64 & & 100 & & 612 & & 59 & \\
\hline
\end{tabular}


Panel C. Constrained IPP regressions.

\begin{tabular}{|c|c|c|c|c|c|c|c|c|c|c|c|c|c|c|c|c|c|c|}
\hline & \multicolumn{2}{|c|}{ Western Europe } & \multicolumn{2}{|c|}{ Eastern Europe } & \multicolumn{2}{|c|}{ North America } & \multicolumn{2}{|c|}{ Latin America } & \multicolumn{2}{|c|}{ Middle East } & \multicolumn{2}{|c|}{ Africa } & \multicolumn{2}{|c|}{ South Asia } & \multicolumn{2}{|c|}{ East Asia } & \multicolumn{2}{|c|}{ Australia } \\
\hline & Coeff. & t-ratio & Coeff. & t-ratio & Coeff. & t-ratio & Coeff. & t-ratio & Coeff. & t-ratio & Coeff. & t-ratio & Coeff. & t-ratio & Coeff. & t-ratio & Coeff. & t-ratio \\
\hline$\sigma_{\mathrm{V}}$ & $3.724 * *$ & 3.0 & $21.794 * *$ & 13.1 & $0.281^{*}$ & 2.2 & $29.449 * *$ & 15.2 & $0.515^{* *}$ & 9.1 & 9.876 & 1.3 & $10.723 * *$ & 10.4 & $13.617^{* *}$ & 11.4 & $0.006^{*}$ & 2.1 \\
\hline $\mathrm{EI} \times \sigma_{\mathrm{V}}$ & $4.864 * *$ & 3.8 & $-17.078 * *$ & -9.6 & & & $-23.455^{* *}$ & -9.6 & $-0.303 * *$ & -6.7 & 13.505 & 1.5 & & & $9.176^{* *}$ & 7.1 & & \\
\hline R-squared & 0.558 & & 0.928 & & 0.302 & & 0.733 & & 0.716 & & 0.450 & & 0.630 & & 0.639 & & 0.256 & \\
\hline Sample Size & 939 & & 62 & & 190 & & 177 & & 52 & & 64 & & 100 & & 612 & & 59 & \\
\hline
\end{tabular}

